\title{
Hepatitis E: Current Status in India and Other Asian Countries
}

\author{
Harsh Kumar ${ }^{1}$, Nassim Kamar² and Dinesh Kumar ${ }^{1 *}$ \\ ${ }^{1}$ School of Bioengineering \& Food Technology, Shoolini University of Biotechnology and Management Sciences, \\ Solan - 173 229, H. P., India. ${ }^{2}$ Department of Nephrology, Dialysis an Organ Transplantation, CHU Rangueil, INSERM \\ U1043, IFR -BMT, University Paul Sabatier, Toulouse, France.
}

\begin{abstract}
Six types of hepatitis infections are accounted for the inflammation of liver in human throughout the world and assigned the letter A, B, C, D, E and G. Out of these, Hepatitis E, caused by Hepatitis E virus (HEV), currently categorized as a member of the genus Hepevirus in the family Hepeviridae. Hepatitis $E$ is considered highly significant, on account of its predominance in both developed and developing nations, due to poor sanitation and cleanliness condition related to drinking water. This review focuses on general epidemiological study update of hepatitis $E$ virus in India and rest of Asia for the selected period and also throws light on some diagnostic approaches available for the same. An extensive literature search was performed with published work and search in PubMed using term "HEV" combined with "country name" restricting the search publication between year 2008 to 2018 for India and 2013 to 2018 for the rest of Asia. The data was analyzed in detail to meet the requirements of the objectives. Study showed that in India the major causes of Hepatitis E was water contaminated with fecal matter. Reports from East and Southeast Asia signified the role of animal reservoir especially the pigs for HEV. Whereas in Indian neighboring countries like Nepal, Pakistan and Western Asia the major cases of Hepatitis E were associated with blood transfusion and pregnancy related cases. Majority of the diagnostic approaches used in India at medical facilities are based on anti-HEV IgM detection. However, the molecular based approaches played very crucial role in HEV detection. It is observed that the incidence of HEV is gradually expanding and its objective range is not only just developing countries, but also showing an enhancement. In overall, there is need for improvements in detection of HEV disease and methodologies used for the development of HEV vaccines.
\end{abstract}

Keywords: Hepatitis E; Hepatitis E virus; anti- HEV antibodies; Seroprevalence.

*Correspondence: dineshkumar@shooliniuniversity.com; +91 1792308000

(Received: 07 January 2019; accepted: 09 February 2019)

Citation: Harsh Kumar, Nassim Kamar and Dinesh Kumar, Hepatitis E: Current Status in India and Other Asian Countries, J Pure Appl Microbiol., 2019; 13(1):141-159 doi: 10.22207/JPAM.13.1.15

C The Author(s) 2019. Open Access. This article is distributed under the terms of the Creative Commons Attribution 4.0 International License which permits unrestricted use, sharing, distribution, and reproduction in any medium, provided you give appropriate credit to the original author(s) and the source, provide a link to the Creative Commons license, and indicate if changes were made. 


\section{INTRODUCTION}

Hepatitis is an augmentation of the liver; a condition that can act naturally restrictant or can lead to cirrhosis, fibrosis (scarring), or liver cancer 1. Researchers have recognized 6 types of hepatitis infections, distinguished by the letters A, B, C, D, E and $G^{2}$. Hepatitis $A$ virus (HAV) was first perceived in 1947 in worldwide yet is exceptionally common in the developing nations and Greenland and further, its worldwide occurrence is diminishing as a direct result of enhanced clean and living conditions ${ }^{2}$. Hepatitis B virus (HBV) is usually transmitted via exposure of contaminated semen, blood, and other body fluids. Hepatitis $C$ virus $(\mathrm{HCV})$ is mostly transmitted due to exposure to infective blood, transfusions of HCV-tainted blood and blood items ${ }^{1}$. Hepatitis $D$ virus or delta virus, is a defective RNA virus that can replicate itself, still it requires simultaneous HBV for assembly and discharge; accordingly, patients with HDV in every case are dually infected with $\mathrm{HBV}^{3}$. The hepatitis $G$ virus (HGV) is again a blood-borne virus spread by tainted blood and blood items ${ }^{2}$. The Hepatitis $E$ virus (HEV), similar to HAV, is transmitted through utilization of debased food and water, and its pervasiveness is regular in both developing and developed countries.

An enteric transmitted non- $A$, non-B hepatitis virus was first reported in view of epidemiological examinations during a flare-up of viral hepatitis in 1978-1979 in Kashmir locale ${ }^{4}$. Soon after the fact, serological testing of sera was done after an extensive episode of hepatitis in New Delhi amid 1955-1956 and two reports in Ahmadabad (1975-1976) and, Pune (19781979 ) in India ${ }^{5}$. Samples from none of the three episodes demonstrated confirmation of acute hepatitis $A$ and just few reports showed markers of acute hepatitis $B$, thus providing important help in confirmation of an enteric non- $A$, and non-B hepatitis. The non- $A$, and non- $B$ hepatitis virus was also found after an episode of mysterious hepatitis in Soviet military in Afghanistan ${ }^{6}$. A member of research team ingested a pooled fecal extract from affected military personnel, and finally suffered with acute hepatitis and small viral particles were identified in his stool through immune electron microscopy ${ }^{6}$. The term hepatitis E virus (HEV) was coined, in view of its enteric transmission and relationship with hepatitis scourges ${ }^{7}$. Currently
HEV is classified as a member of genus Hepevirus in the family Hepeviridae ${ }^{8}$. This review focuses on general epidemiological study update of HEV in India and rest of Asia for the selected period and also throws light on diagnostic approaches available for the same. For this study, keyword literature search was performed in PubMed using term "HEV" combined with "country name" restricting the search publication between year 2008 to 2018 for India and 2013 to 2018 for the rest of Asia. Any article that has been published between 2008 and 2018, but, in which sampling data was taken before 2008 , has not been included. Similarly for rest Asia, in which sampling data was taken before 2013, has not been included.

\section{Molecular Biology and Classification of HEV}

$\mathrm{HEV}$ is a non-enveloped virus, with an icosahedral capsid of 27- $34 \mathrm{~nm}$ size. The virus possesses a single-stranded, positive-sense, 7.2-kb RNA genome showing capping and polyadenylation at the 5 ' and 3 ' ends, individually 7,9 . The HEV genome has three open reading frames (ORFs) as shown in figure 1. ORF1 encodes a protein of 1,693 amino acids comprising functional domains itself present in the nonstructural proteins of other positive-strand RNA viruses ${ }^{10}$. These functional domains contain cysteine protease, methyltransferase, RNA helicase, and RNA-dependent RNA polymerase areas. ORF2 encodes 660 amino acids, a viral capsid protein responsible for virion assembly, immunogenicity, and interaction with target cells ${ }^{11-14}$. The ORF2 protein having three linear domains: the shell domain (S) (amino acids 129 to 319), the center domain (M) (amino acids 320 to 455), and the protruding domain (P) (amino acids 456 to 606) harboring the neutralizing epitope(s) ${ }^{15-17,8,18}$. ORF3, which overlaps ORF2, encodes a small protein of 113 or 114 amino acids, is associated with virion morphogenesis and discharge ${ }^{19-}$ ${ }^{21}$. The HEV genomes of a few topographically distinctive isolates demonstrate a high level of sequence conservation ${ }^{22}$. Four phylogenetically unique genotypes have been characterized, which disseminate by geographic regions. In Asian and African regions HEV strains belonging to genotype 1 was more prevalent, genotype 2 incorporates the single Mexican HEV strain and few of variants identified as endemic in African nations. In industrialized nations genotype 3 with human and 
swine HEV strains are common, whereas in East Asia especially China, Taiwan and Japan, genotype 4 incorporates swine HEV and human strains ${ }^{23}$. The avian HEV was proposed to exhibit a place with another genotype ${ }^{5}$, but this has not yet been affirmed ${ }^{24,25 .}$

\section{HEV in India from 2008-2018}

At first the epidemics of acute hepatitis

$E$, transmitted by means of polluted water, were reported in developing nations including India. Now the examples have changed with pace of time; and water-borne fecal-oral transmission is unable to justify the locally-acquired cases of hepatitis $E$ in developed countries, as sterile and clean conditions have improved a lot. In such nations, now the zoonotic transmission via ingestion of uncooked meat has been considered to be the principle cause of HEV infection ${ }^{26,27}$. Defiled water is still considered the prime suspect for spread of hepatitis $E$ (Table 1 ) although there are also some reports based on transfusion-mediated HEV transmissions ${ }^{28}$. In, 2011, a flare-up of water linked hepatitis in Bathinda city, Punjab, showed the presence of $64.19 \%$ cases of HEV in the blood tests of the patients ${ }^{29}$. Study showed that the poverty and lack sanitation is firmly related with HEV infection. Blood tests reports gathered from the patients, in Nanital, Uttrakhand revealed the presence of high rate of $\mathrm{HEV}$ in drinking water due to sewage tainting of drinking water supply ${ }^{30}$. Two suburban (Nawanshahar and Palsora) of Punjab were suspected with the viral hepatitis episode related with sewage defilement of drinking water ${ }^{31}$. Another research in similar zones, compared the acute viral hepatitis patients (AVH) along with healthy and subclinical subjects (apparently healthy) and observed that both the strains were having a common source of infection, but with low viral load ${ }^{32}$. Another research also reported the flare-up of HEV in Northwest region of Punjab with fecal contamination of drinking water among 21-30 years of age group ${ }^{33}$. Vertical transmission of HEV contaminations at the rate of $78.9 \%$ (based on IgM, IgG anti-HEV and HEV RNA positive) was confirmed in newly conceived babies ${ }^{34}$. The biochemical, clinical, serological and virological profile of survived children showed that HEV contamination (mother-to-foetus transmission) in neonates is a self-restricting disease and does not cause unending viremia or delayed clinical course.
Duel infection of hepatitis $E$ and $B$ was accounted in Delhi for first time, and 26 patients with double infections showed that hepatitis B virus (HBV) infected chronic carriers patients were secondarily infected with HEV and resulted in acute hepatitis ${ }^{35}$. A report from Ahmadabad, Gujarat showed $4.78 \% \mathrm{HEV}$ cases among the blood donors ${ }^{36}$. The age of the study group ranged from 18 to 60 years and age of 41-60 years tended to have higher HEV seroprevalence rates of $10.34 \%$ (positive IgM anti-HEV). In general less seroprevalence among blood donors is connected with proper sanitation facilities in their respective areas and to some extent the social status. Anti-HEV IgG rate was $60.5 \%$ among the blood donors in the range of 18 and 63 years in Lucknow and showed comparable anti-HEV rates among male and female ${ }^{28}$. A hospital-based investigation in West Bengal, revealed the detection of anti-HEV IgG in $41.8 \%$ AVH patients and $23 \%$ in healthy people. The high prevalence of anti-HEV IgG in healthy control shows the presence of subclinical infection ${ }^{37}$. Another hospital-based investigation showed that low HEV prevalence in kids (9.79\%) may be related with improvement in living standards of the population ${ }^{38}$. HEV antigen measure can be used as an extra analytic marker to show the viral replication in HEV infection ${ }^{39}$. HEV strains isolated from sewage samples collected from Vellore belonged to genotype 1 and have shown 94-100\% sequence similarity with HEV strains have isolated earlier from acute hepatitis $E$ cases at Vellore hospital ${ }^{40}$. An examination report from Punjab has shown pigs as a reservoir of $\mathrm{HEV}$ with $65.0 \%$ rate and high seropositivity (18.70\%) in developing pigs ${ }^{41}$. A study in Lucknow medical hospital reported the presence of anti-HEV IgG and IgM in the renal transplant patients, however all the results were negative for HEV RNA and the finding suggested the infrequent nature of chronic infection with genotype $1 \mathrm{HEV}^{42}$.

\section{Integrated Disease Surveillance Programme (IDSP)}

As per IDSP, India report (2018), from 2013 to 2018 an aggregate of 22671 cases of HEV have been reported and out of these 152 deaths were reported. Similarly, 1667 cases of suspected hepatitis have additionally been reported with 1 death case as shown in Table $2^{43}$. In all the cases, polluted drinking water with fecal containment 
Kumar et al. J Pure Appl Microbiol, 13(1), 141-159 | March 2019 | DOI 10.22207/JPAM.13.1.15

Table 1. Prevalence of Hepatitis E Virus (HEV) cases in India from 2008- 2018

\begin{tabular}{|c|c|c|c|c|c|c|c|}
\hline $\begin{array}{l}\text { Region of HEV } \\
\text { Occurrence }\end{array}$ & Study Period & $\begin{array}{l}\text { Study } \\
\text { Population }\end{array}$ & $\begin{array}{l}\text { Sample } \\
\text { Size }\end{array}$ & $\begin{array}{l}\text { Source } \\
\text { of } \\
\text { Sample }\end{array}$ & $\begin{array}{l}\text { Detection } \\
\text { of Anti- HEV } \\
\text { Antibodies } \\
\text { (\%) }\end{array}$ & $\begin{array}{l}\text { Detection } \\
\text { of HEV } \\
\text { RNA (\%) }\end{array}$ & References \\
\hline Srinagar & NS & $\begin{array}{l}\text { New Born } \\
\text { Babies }\end{array}$ & 19 & $\begin{array}{l}\text { Blood } \\
\text { Serum }\end{array}$ & $\begin{array}{l}\lg M(63.15) \\
\operatorname{lgG}(15.78)\end{array}$ & $\begin{array}{l}\text { RNA } \\
(52.63)\end{array}$ & 34 \\
\hline New Delhi & 1 year & $\begin{array}{l}\text { AVH } \\
\text { patients* }\end{array}$ & 1141 & $\begin{array}{l}\text { Blood } \\
\text { Serum }\end{array}$ & $\operatorname{lgM}(32.16)$ & ND & 35 \\
\hline Bathinda & 2011 & $\begin{array}{l}\text { AVH } \\
\text { patients }^{*}\end{array}$ & 81 & $\begin{array}{l}\text { Blood } \\
\text { Serum }\end{array}$ & $\operatorname{lgM}(64.19)$ & ND & 29 \\
\hline Lucknow & 2011-2012 & $\begin{array}{l}\text { AVH } \\
\text { patients }\end{array}$ & 267 & $\begin{array}{l}\text { Blood } \\
\text { Serum }\end{array}$ & $\operatorname{lgM}(17.97)$ & ND & 38 \\
\hline New Delhi & 2010-2012 & $\begin{array}{l}\text { AVH } \\
\text { patients }^{*}\end{array}$ & 156 & $\begin{array}{l}\text { Blood } \\
\text { Serum }\end{array}$ & $\operatorname{lgM}(78.51)$ & $\begin{array}{l}\text { RNA } \\
(35.71)\end{array}$ & 39 \\
\hline Vellore & 2009-2010 & NA & 144 & Sewage & ND & $\begin{array}{l}\text { RNA } \\
(55.6)\end{array}$ & 40 \\
\hline Kolkata & $2012-2013$ & $\begin{array}{l}\text { AVH } \\
\text { patients* }\end{array}$ & 285 & $\begin{array}{l}\text { Blood } \\
\text { Serum }\end{array}$ & $\begin{array}{l}\lg M(35.04) \\
\operatorname{lgG}(43.58)\end{array}$ & ND & 37 \\
\hline Ahmadabad & $\begin{array}{l}\text { August - } \\
\text { December } \\
2012\end{array}$ & $\begin{array}{l}\text { Blood } \\
\text { donors }\end{array}$ & 460 & $\begin{array}{l}\text { Blood } \\
\text { Serum }\end{array}$ & $\operatorname{lgM}(4.78)$ & ND & 36 \\
\hline Nainital & $\begin{array}{l}\text { January- } \\
\text { March } 2013\end{array}$ & $\begin{array}{l}\text { AVH } \\
\text { patients* }\end{array}$ & 240 & $\begin{array}{l}\text { Blood } \\
\text { Serum }\end{array}$ & $\operatorname{lgM}(76.92)$ & ND & 30 \\
\hline $\begin{array}{l}\text { Pulsora and } \\
\text { Nawasahar }\end{array}$ & 2012 & $\begin{array}{l}\text { Healthy } \\
\text { Persons }\end{array}$ & 67 & $\begin{array}{l}\text { Blood } \\
\text { Serum }\end{array}$ & $\operatorname{lgG}(61.9)^{* *}$ & ND & 32 \\
\hline $\begin{array}{l}\text { Pulsora and } \\
\text { Nawasahar }\end{array}$ & $\begin{array}{l}\text { March- } \\
\text { April } 2012\end{array}$ & $\begin{array}{l}\text { Icteric } \\
\text { Patients }\end{array}$ & 60 & $\begin{array}{l}\text { Blood } \\
\text { Serum } \\
\text { Saliva }\end{array}$ & $\begin{array}{l}\operatorname{IgM}(86.66)^{* *} \\
\operatorname{IgM}(47.61)^{* * *}\end{array}$ & $\begin{array}{l}\text { RNA } \\
(30.0)^{* *} \\
\text { NA }\end{array}$ & 31 \\
\hline Ludhiana & NS & $\begin{array}{l}\text { Pigs } \\
\text { Healthy } \\
\text { Humans }\end{array}$ & $\begin{array}{l}320 \\
360\end{array}$ & $\begin{array}{l}\text { Stool } \\
\text { Blood } \\
\text { Serum } \\
\text { Stool }\end{array}$ & $\begin{array}{l}\text { ND } \\
\operatorname{lgG}(60.48)\end{array}$ & $\begin{array}{l}\text { RNA } \\
(8.75) \\
\text { ND } \\
\text { RNA } \\
(0.27)\end{array}$ & 41 \\
\hline Amritsar & 2015-2016 & $\begin{array}{l}\text { AVH } \\
\text { patients* }\end{array}$ & 95 & $\begin{array}{l}\text { Blood } \\
\text { Serum }\end{array}$ & $\operatorname{lgM}(68.42)$ & ND & 33 \\
\hline Lucknow & $\begin{array}{l}\text { June-July 2016, } \\
\text { November- } \\
\text { December } \\
2016\end{array}$ & $\begin{array}{l}\text { Blood } \\
\text { donors }\end{array}$ & 1799 & $\begin{array}{l}\text { Blood } \\
\text { Serum }\end{array}$ & $\operatorname{lgG}(60.5)$ & ND & 28 \\
\hline Lucknow & NS & $\begin{array}{l}\text { Kidney } \\
\text { transplant } \\
\text { patients }\end{array}$ & 205 & $\begin{array}{l}\text { Blood } \\
\text { Serum }\end{array}$ & $\begin{array}{l}\operatorname{lgG}(25.3) \\
\operatorname{IgM}(6.8)\end{array}$ & ND & 42 \\
\hline
\end{tabular}

NA (Not Specified); ND (Not Determined)

${ }^{*}$ Acute Viral Hepatitis; ${ }^{* *}$ Two cities collective; ${ }^{* * *}$ Nawasahar samples only

was the primary reason for flare-ups and anti- out by the researchers in Asia from year 2013 up HEV IgM was well distinguished in patients' blood to 2018 have been documented in Table 3 and serum.

HEV in Asia from 2013-2018 discussed in the following sections:

Cases Related to Animals and Animal Foods

Different epidemiological studies carried

Zoonotic transmission through direct 
contact or food items from the infected animals have mostly accounted for HEV infections in human beings. In China, several cases of HEV in the form of HEV RNA and Anti-HEV antibodies have been reported in animal food products. In rodents shrews, a rate of HEV $1.66 \%$ was observed and phylogenetic analysis revealed $84.7 \%$ of nucleotide sequence similarity with hepatitis E virus (rat/ R63/DEU/2009) in Germany and 84.9\% sequence similarity with HEV isolate (Vietnam-105) with rats in Vietnam ${ }^{44}$. Three HEV strains isolated from the wild rats in one of the Chinese city indicated nucleotide sequence having 88.9-94.3\% and 93.4$94.3 \%$ similarity respectively with Vietnamese rats and HEV strain V-105. This study also highlighted the possibility of transmission of HEV between rats as fecal-oral route in these were similar to human HEV ${ }^{45}$. From 17 mammal species an aggregate of 822 fecal samples and from 24 avian species 67 fecal samples were examined for the presence of HEV in other region of China, and apart from swine and rabbits none of the mammalian species showed presence of HEV RNA46. A high positive rate of HEV RNA in swine, made swine as important reservoir for $\mathrm{HEV}$, and, nucleotide sequence similarity of $98 \%$ with genotype 4 affirmed the event of HEV transmission from swine to people. On the other hand, avian HEV RNA was detected from sick (with dual infection of HEV and Marek's disease virus) and healthy chickens; and all three HEV strains indicated $95.5 \%-97.9 \%$ group similarity with chicken from Europe and different parts of China ${ }^{47}$. Research conducted on pigs in Tibet demonstrated that the female pigs had 1.4

Table 2. Hepatitis E cases in India from 2013- 2018 based on Hospital findings

\begin{tabular}{ccccc}
\hline Year & $\begin{array}{c}\text { No. of } \\
\text { Cases } \\
\text { Reported }\end{array}$ & $\begin{array}{c}\text { No. of } \\
\text { Deaths }\end{array}$ & $\begin{array}{c}\text { Suspected } \\
\text { Cases }\end{array}$ & $\begin{array}{c}\text { No. of } \\
\text { Deaths }\end{array}$ \\
\hline 2013 & 1153 & 1 & 400 & 0 \\
2014 & 1097 & 12 & 746 & 0 \\
2015 & 4460 & 26 & 145 & 0 \\
2016 & 13997 & 112 & 90 & 0 \\
2017 & 1611 & 1 & 120 & 1 \\
$2018^{*}$ & 353 & 0 & 166 & 0 \\
\hline
\end{tabular}

*upto $33^{\text {rd }}$ Week, data has been included. Complied from source: http://www.idsp.nic.in times higher danger of acquiring infection when contrasted with male pigs and additionally pigs with age $>1$ year had 2 times higher danger of being positive ${ }^{48}$. Comparative examination of Tibetan pigs and isolated HEV strains showed similarity with genotype $4{ }^{49}$. HEV strains isolated from goat showed similarity with genotype 4 and shared $99.9 \%-99.8 \%$ homology with swine HEV strains and also showed $99.6 \%-99.7 \%$ similarity to human HEV and share $99.6 \%-99.7 \%$ likeness to cow HEV, thus showing cross-species transmission ${ }^{50}$. Another investigation on goat, exhibited $2 \mathrm{HEV}$ strains belonging to genotype 4 and showing sequence similarity with cows, humans and pigs ${ }^{51}$. Blood sera gathered from sheep and sheep butchers in China showed 35.2\% anti-HEV antibody in sheep blood, $57.7 \%$ in butcher's blood, and among sheep the most elevated cases were among adult in contrast with young ones and all the isolates belonged to genotype $4{ }^{52}$. Study was done in HEV patients and different food items in Hong Kong and all HEV patients had 100\% IgM antiHEV and $82 \%$ of HEV RNA from pig liver, intestine and oysters ${ }^{53}$. Experts from Japan have shown the presence of HEV in wild boars in few territories and phylogenetic tree examination showed that the majority of the HEV strains resembled with genotype $3{ }^{54}$. Another report from Japan found the highest positivity of HEV RNA among 3-months old pigs ${ }^{55}$. HEV was also additionally found in Japanese bats and BLAST study showed the highest sequence similarity with German strain. Although, the research only commented on the geographical distribution of BatHEV among different bat species; yet it failed to connect the presence of same HEV strains in Japanese and German bats ${ }^{56}$. In South Korea, fecal sample of the pigs were gathered from 14 farms in which 5 farms contained HEV-3, while other 2 had HEV-4 only ${ }^{57}$. HEV RNA detected from rabbit's feces in Korea is arranged into rabbit clad within HEV-3 and one of the rabbit HEV isolate was named as KOR-RB-1. The full length genome of such isolate showed $86.8 \%, 86.6 \%$ and $80.2-84.3 \%$ nucleotide similarity with rabbit HEV strains in China, USA and France respectively ${ }^{58}$. HEV from specific- pathogen free (SPF) rabbits purchased from the local sellers in Korea, showed $86.1-86.8 \%, 82.4-85.7 \%$, and $86.4-89.7 \%$ similarities respectively with rabbit HEV isolated from USA, France and China ${ }^{59}$. A 
Kumar et al. J Pure Appl Microbiol, 13(1), 141-159 | March 2019 | DOI 10.22207/JPAM.13.1.15

Table 3. Prevalence of Hepatitis E Virus (HEV) cases in Asia from 2013- 2018

\begin{tabular}{|c|c|c|c|c|c|c|c|c|}
\hline $\begin{array}{l}\text { Asian } \\
\text { Parts }\end{array}$ & $\begin{array}{l}\text { Region of HEV } \\
\text { Occurrence }\end{array}$ & $\begin{array}{l}\text { Study } \\
\text { Period }\end{array}$ & $\begin{array}{c}\text { Study } \\
\text { Population }\end{array}$ & $\begin{array}{l}\text { Sample } \\
\text { Size }\end{array}$ & $\begin{array}{c}\text { Source } \\
\text { of Sample }\end{array}$ & $\begin{array}{l}\text { Detection } \\
\text { of Anti- HEV }\end{array}$ & $\begin{array}{c}\text { Detection } \\
\text { of HEV RNA (\%) } \\
\text { Antibodies (\%) }\end{array}$ & References \\
\hline & China & $\begin{array}{l}\text { December } \\
\text { 2011- } \\
\text { September } \\
2012\end{array}$ & Wild Rats & 713 & Blood & $\begin{array}{l}\operatorname{IgG}(23.3) \\
\text { Serum }\end{array}$ & $\begin{array}{l}\text { RNA (1.68) } \\
\operatorname{IgM}(8.3 \%)\end{array}$ & 45 \\
\hline & China & NS & $\begin{array}{l}\text { Healthy } \\
\text { Persons }\end{array}$ & 1638 & $\begin{array}{l}\text { Blood } \\
\text { Serum }\end{array}$ & $\begin{array}{l}\operatorname{lgG}(12.03) \\
\operatorname{IgM}(1.89)\end{array}$ & RNA (0.6) & 73 \\
\hline & China & $\begin{array}{l}\text { January- } \\
\text { Feburary }\end{array}$ & $\begin{array}{l}\text { Healthy } \\
\text { Sheep }\end{array}$ & 575 & $\begin{array}{l}\text { Blood } \\
\text { Serum }\end{array}$ & $\begin{array}{c}\text { Anti-HEV } \\
\text { antibody (35.2) }\end{array}$ & ND & 52 \\
\hline & & 2014 & & & & Liver & ND & RNA(5.33) \\
\hline & & & & & & & $\begin{array}{l}\text { Both IgG and } \\
\operatorname{IgM}(2.93)\end{array}$ & \\
\hline & China & NS & $\begin{array}{l}\text { Mammal } \\
\text { Species }^{*}\end{array}$ & 822 & Fecal & ND & $\begin{array}{c}\text { RNA }(33.0,30.0 \\
92.0)^{* * *} ; \text { RNA } \\
(5.0)^{* * * *}\end{array}$ & 46 \\
\hline & & & Avian Species ${ }^{* *}$ & 24 & Fecal & ND & ND & \\
\hline & China & NS & $\begin{array}{l}\text { Healthy } \\
\text { Chickens }\end{array}$ & 5 & Liver & ND & RNA (80.0) & 47 \\
\hline \multirow[t]{10}{*}{ East } & & & $\begin{array}{l}\text { Chickens } \\
\text { with } \mathrm{MD}^{* * * * *} \\
\text { and } \mathrm{HEV}\end{array}$ & 25 & Liver & ND & RNA (56.0\%) & \\
\hline & China & $2013-2014$ & AVH patients & 62 & $\begin{array}{l}\text { Blood } \\
\text { Serum } \\
\text { Fecal }\end{array}$ & $\begin{array}{c}\operatorname{IgG}(76.0) \\
\operatorname{IgM}(100) \\
\text { ND }\end{array}$ & $\begin{array}{c}\text { ND } \\
\text { RNA (58.0) }\end{array}$ & 83 \\
\hline & China & May-July 2015 & Sewage & 152 & Sewage & ND & RNA (1.32) & 101 \\
\hline & China & 2015-2016 & $\begin{array}{l}\text { Healthy } \\
\text { Goats }\end{array}$ & 106 & $\begin{array}{l}\text { Blood } \\
\text { Serum } \\
\text { Fecal } \\
\text { Milk }\end{array}$ & $\begin{array}{c}\operatorname{IgG}(14.29) \\
\operatorname{IgM}(3.57) \\
\text { ND } \\
\text { ND }\end{array}$ & $\begin{array}{c}\text { ND } \\
\text { RNA (74.07) } \\
\text { RNA (100) }\end{array}$ & 50 \\
\hline & China & $2013-2016$ & $\begin{array}{l}\text { Rodents } \\
\text { Shrews }\end{array}$ & $\begin{array}{l}225 \\
196\end{array}$ & $\begin{array}{l}\text { Tissue }{ }^{* * * * * *} \\
\text { Tissue } \\
\text { ******* }\end{array}$ & $\begin{array}{l}\text { ND } \\
\text { ND }\end{array}$ & $\begin{array}{l}\text { RNA (2.6) } \\
\text { RNA (0.5) }\end{array}$ & 44 \\
\hline & China & $\begin{array}{c}\text { January- } \\
\text { March2007 }\end{array}$ & $\begin{array}{l}\text { Healthy } \\
\text { Goats }\end{array}$ & $\begin{array}{c}120 \\
50\end{array}$ & $\begin{array}{l}\text { Blood Serum } \\
\text { Liver }\end{array}$ & $\begin{array}{c}\lg (46.7) \\
\text { ND }\end{array}$ & $\begin{array}{c}\text { ND } \\
\text { RNA (4.0) }\end{array}$ & 51 \\
\hline & China & 2014-2015 & $\begin{array}{c}\text { Healthy Persons } \\
\text { Healthy Pigs }\end{array}$ & $\begin{array}{l}600 \\
453\end{array}$ & $\begin{array}{l}\text { Blood Serum } \\
\text { Blood Serum }\end{array}$ & $\begin{array}{l}\operatorname{lgG}(39.33) \\
\operatorname{lgG}(39.33)\end{array}$ & $\begin{array}{l}\text { ND } \\
\text { ND }\end{array}$ & 49 \\
\hline & China & $2012-2015$ & $\begin{array}{l}\text { Cancer } \\
\text { Patients }\end{array}$ & 950 & Blood Serum & $\begin{array}{l}\operatorname{lgG}(22.7) \\
\operatorname{IgM}(4.2)\end{array}$ & ND & 91 \\
\hline & & & $\begin{array}{c}\text { Healthy } \\
\text { Individuals }\end{array}$ & 950 & Blood Serum & $\begin{array}{l}\operatorname{IgG}(22.7) \\
\operatorname{IgM}(2.1)\end{array}$ & ND & \\
\hline & China & 2015 & $\begin{array}{c}\text { Healthy } \\
\text { Individuals }\end{array}$ & 1912 & Blood Serum & $\begin{array}{c}\operatorname{lgG}(66.58), \\
(3.35) \operatorname{lgM}(0.84) \\
\text { and Both IgG } \\
\text { and IgM }\end{array}$ & ND & 76 \\
\hline
\end{tabular}


Table 3. Continued

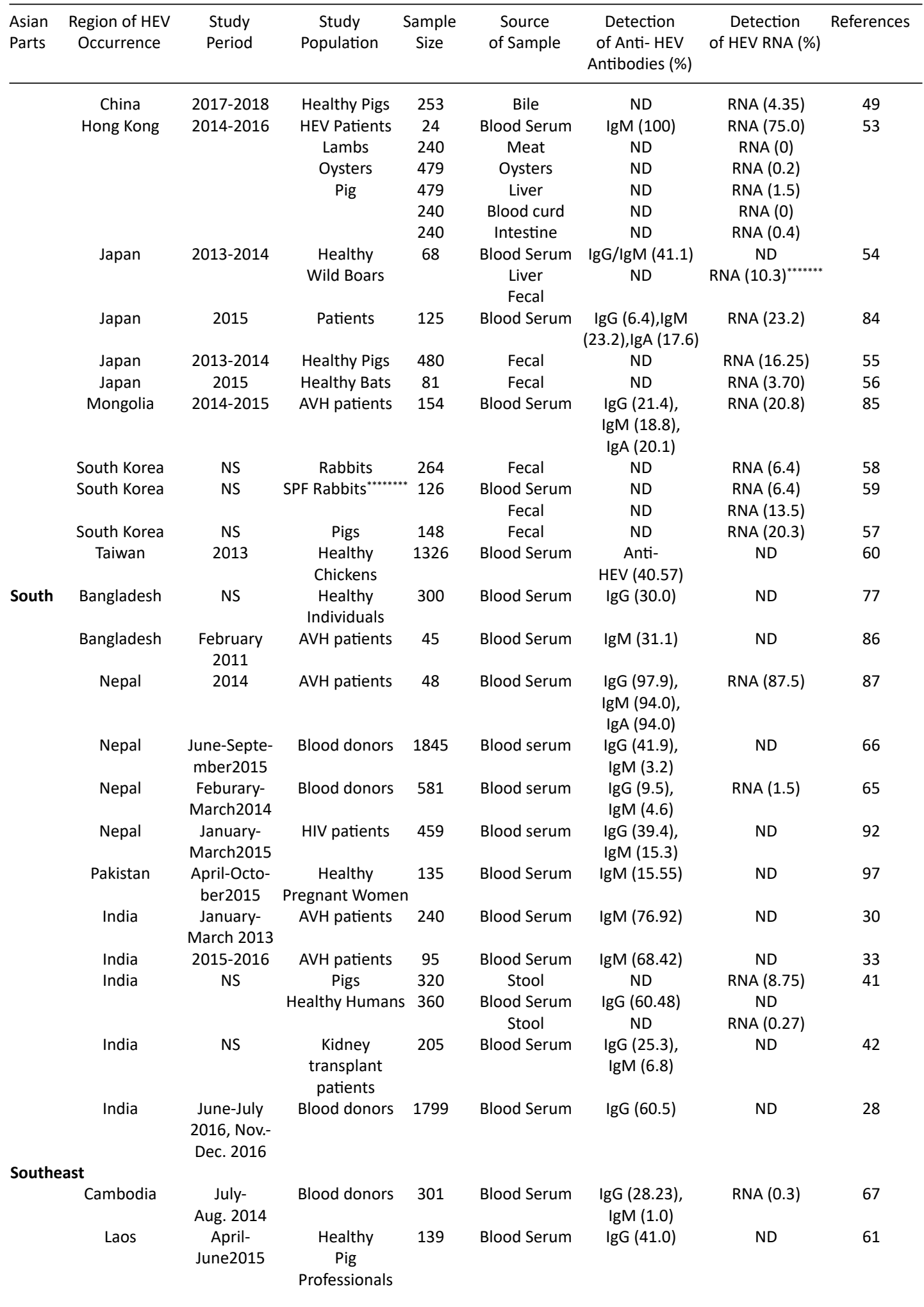


Table 3. Continued

\begin{tabular}{|c|c|c|c|c|c|c|c|c|}
\hline $\begin{array}{l}\text { Asian } \\
\text { Parts }\end{array}$ & $\begin{array}{l}\text { Region of HEV } \\
\text { Occurrence }\end{array}$ & $\begin{array}{l}\text { Study } \\
\text { Period }\end{array}$ & $\begin{array}{c}\text { Study } \\
\text { Population }\end{array}$ & $\begin{array}{l}\text { Sample } \\
\text { Size }\end{array}$ & $\begin{array}{l}\text { Source } \\
\text { of Sample }\end{array}$ & $\begin{array}{c}\text { Detection } \\
\text { of Anti- HEV } \\
\text { Antibodies (\%) }\end{array}$ & $\begin{array}{c}\text { Detection } \\
\text { of HEV RNA (\%) }\end{array}$ & References \\
\hline & & $\begin{array}{c}\text { March- } \\
\text { April2016 }\end{array}$ & Slaughter Pigs & 274 & Blood Serum & $\operatorname{IgG}(54.0)$ & ND & \\
\hline & Laos & 2015 & $\begin{array}{l}\text { Healthy } \\
\text { Ruminants }\end{array}$ & 186 & $\begin{array}{l}\text { Serum } \\
\text { Fecal }\end{array}$ & $\begin{array}{l}\text { Anti- HEV } \\
\text { Ab (7.0) }\end{array}$ & $\begin{array}{c}\text { ND } \\
\text { RNA }(0.0)\end{array}$ & 78 \\
\hline & & 2016 & $\begin{array}{l}\text { Healthy } \\
\text { Individuals }\end{array}$ & 386 & Blood Serum & $\begin{array}{l}\operatorname{IgG}(51.8) \\
\operatorname{IgM}(17.5)\end{array}$ & ND & \\
\hline & Thailand & $\begin{array}{c}\text { March- } \\
\text { Ocober2014 }\end{array}$ & $\begin{array}{l}\text { Healthy } \\
\text { Individuals }\end{array}$ & 721 & Blood Serum & $\begin{array}{c}\operatorname{lgG} \\
(37.3)^{* * * * * * * *} ; \\
\operatorname{lgG}(8.9)^{* * * * * * * *}\end{array}$ & ND & 79 \\
\hline & Thailand & 2014-2015 & Pig; Food Items & 2205 & Tissue $e^{* * * * *}$ & ND & RNA (0.23) & 62 \\
\hline & & & Pig & 1273 & Bile, Fecal & ND & RNA (3.93) & \\
\hline \multirow[t]{2}{*}{ North } & Russia & NS & $\begin{array}{l}\text { Immune } \\
\text { Deficient } \\
\text { Children }\end{array}$ & 87 & Blood Serum & $\begin{array}{l}\operatorname{lgG}(5.7) \\
\operatorname{IgM}(1.6)\end{array}$ & ND & 93 \\
\hline & & & $\begin{array}{l}\text { Healthy } \\
\text { Children }\end{array}$ & 3122 & Blood Serum & $\begin{array}{l}\operatorname{IgG}(1.4) \\
\operatorname{IgM}(0.25)\end{array}$ & ND & \\
\hline \multirow[t]{14}{*}{ Western } & Iran & NS & $\begin{array}{l}\text { Pregnant } \\
\text { Healthy } \\
\text { Women }\end{array}$ & 136 & Blood Serum & $\lg G(3.6)$ & ND & 98 \\
\hline & Iran & NS & ESRD patients & 47 & Blood Serum & $\operatorname{IgG}(10.6)$ & ND & 94 \\
\hline & Iran & $\begin{array}{l}\text { Feburary- } \\
\text { July2014 }\end{array}$ & Blood donors & 510 & Blood Serum & $\begin{array}{l}\text { IgG (46.1), } \\
\text { IgM (1.4) }\end{array}$ & ND & 68 \\
\hline & Iran & $\begin{array}{l}\text { September- } \\
\text { Oct. } 2013\end{array}$ & Blood donors & 628 & Blood Serum & $\lg G(16.7)$ & ND & 69 \\
\hline & Iran & $2013-2014$ & $\begin{array}{l}\text { Thalassemia } \\
\text { patients }\end{array}$ & 110 & Blood Serum & $\begin{array}{l}\operatorname{IgG}(10.0) \\
\operatorname{IgM}(1.8)\end{array}$ & ND & 95 \\
\hline & Iran & $\begin{array}{c}\text { July- } \\
\text { Dec. } 2014\end{array}$ & Blood donors & 559 & Blood Serum & $\operatorname{lgG}(8.1)$ & ND & 70 \\
\hline & Iran & $\begin{array}{l}\text { January- } \\
\text { March } 2014\end{array}$ & Blood donors & 700 & Blood Serum & $\begin{array}{l}\operatorname{IgG}(6.0) \\
\operatorname{IgM}(0.71)\end{array}$ & RNA (12.0) & 71 \\
\hline & Iran & $2016-2017$ & $\begin{array}{l}\text { Healthy } \\
\text { Pregnant } \\
\text { Women }\end{array}$ & 1331 & Blood Serum & $\begin{array}{l}\operatorname{IgG}(0.83) \\
\operatorname{IgM}(0.47)\end{array}$ & ND & 99 \\
\hline & Isreal & $2013-2015$ & AVH patients & 49 & Blood Serum & ND & RNA (6.1) & 102 \\
\hline & & & Sewage & 169 & Sewage & ND & RNA (8.8) & \\
\hline & Jordan & 2015-2016 & $\begin{array}{l}\text { Healthy } \\
\text { Individuals }\end{array}$ & 450 & Blood Serum & $\operatorname{lgG}(30.9)$ & ND & 80 \\
\hline & Qatar & 2013-2016 & Blood donors & 5854 & Blood Serum & $\begin{array}{l}\operatorname{lgG}(20.5) \\
\operatorname{IgM}(0.58)\end{array}$ & RNA (11.7) & 72 \\
\hline & Turkey & NS & $\begin{array}{c}\text { Healthy } \\
\text { Primary } \\
\text { school children }\end{array}$ & 185 & Blood Serum & IgG/IgM (12.4) & ND & 81 \\
\hline & UAE & $\begin{array}{l}\text { January- } \\
\text { July2013 }\end{array}$ & $\begin{array}{l}\text { Adult } \\
\text { Healthy } \\
\text { Camels }\end{array}$ & 203 & Fecal & ND & RNA (1.47) & 63 \\
\hline
\end{tabular}

NS (Not Specified); ND (Not Determined)

"(Swine, Rabbits, Foxes, Sheep, Sika Deer, Wild Boars, Yaks, Camels, Asiatic Black Bears, African Lion, Red Pandas, Civets, Wolves, Jackals,); ${ }^{* *}$ Birds(Species not defined); ${ }^{* * *}$ Pig stool RNA; ${ }^{* * *}$ Rabbit stool RNA; ${ }^{* * * *}$ Marek's disease; ${ }^{* * * * *}$ Liver, Lung and Intestine; ${ }^{* * * * * * *}$ Collective RNA (Liver and Fecal); ${ }^{* * * * * * *}$ Specific-pathogens free; ${ }^{* * * * * * * *}$ Different sampling site

report from Taiwan, showed the presence of Avian HEV (aHEV) in chickens, and its full genome (6,653 bp) called TWNaHEV demonstrated $98 \%$ close connection between the aHEV genotype 4 strains from Hungry ${ }^{60}$. A study conducted in Laos has showed $54.0 \%(136 / 252)$ of the slaughter pigs seropositive for anti-HEV IgG ${ }^{61}$. HEV RNA was reported in the pork and pork items sold in open 
air markets in Bangkok, Thailand ${ }^{62}$. A new HEV genotype was observed in camel feces in United Arab Emirates in 2013 and was named as DcHEV (dromedary camel HEV) ${ }^{63}$.

\section{Cases Related to Blood Donors}

Transfusion safety is having utmost significance in transfusion services and with time the transfusion safety is enhancing with screening of blood and blood items with regular introduction of better tests. The presence of anti-HEV IgG antibody has generally been taken as proof of prior exposure to HEV ${ }^{64}$. Report from Nepal showed the presence of hepatitis $E$ viremia among the healthy blood donors with a rate of $1.54 \%$ and phylogenetic examination of these samples demonstrates the infection with homology of $95 \%$ with strain from India and Nepal outbreak in $2014{ }^{65}$. An investigation conducted to check HEV seroprevalence among the blood donors in Nepal after devastating earthquakes in 2015 showed $3.0 \%$ donors positive for anti-HEV $\operatorname{IgM}$, and $2.7 \%$ were found with both HEV IgM and IgG antibodies. HEV IgM predominance was related with donors having history of jaundice and pork consumption was found to be a possible risk factor for such infection. Anti-HEV IgG positivity rate was $41.9 \%$ and the predominance HEV IgG increased with increasing age and was higher in repeat blood donors, with a history of jaundice and pork consumption ${ }^{66}$. Among the blood donors in Cambodia 28.2\% of Anti-HEV IgG were found ${ }^{67}$. One of the isolate belonged to genotype 3 and researcher found a strong genetic link between human transfusion-related HEV-3 strain and one aquatic HEV-3 strain from the different geographical regions in Cambodia. The study suggested that river water, contaminated with HEV-3 by human feces, may be additional source of HEV-3 infection in Cambodia. In another report the blood samples collected from the donors in one of the Iranian city showed $46.1 \%$ anti-HEV IgG antibody with noteworthy rate of anti-HEV seroprevalence in subjects in the age group of 6170 years $(90.9 \%)$. On the other hand, the amount of anti-HEV IgM was $1.4 \%$ and the rate was high among the subjects with $18-30$ years of age ${ }^{68}$. A study in the healthy blood donors in Bushehr city, Iran showed that the anti-HEV IgG was $39.1 \%$ in the age group $40-60$ years and $71.4 \%$ in the group older than 60 years: thus indicating that
anti-HEV prevalence increased with increase of age ${ }^{69}$. In Tehran, Iran; the HEV seroprevalence was essentially extraordinary with regards to level of education among the healthy blood donors and showed low HEV predominance in university degree holders ${ }^{70}$. A study on the blood donors in Southwest of Iran showed 7.1\% of HEV seroprevalence (on the basis of HEV IgG and IgM antibodies), however the HEV RNA from all the isolates reveled $88 \%$ to $99 \%$ nucleotide sequence similarity with HEV genotype $1^{71}$. Similarly, $20.7 \%$ anti-HEV seroprevalence was found among the blood donors in Qatar amid 2013 and $2016{ }^{72}$. The high seroprevalence in Qatar may be due to blended population where a substantial extent is originating from hyperendemic nations such as, Egypt and Indian subcontinent.

\section{Cases Related to General Population}

A large number of HEV infection cases were also reported from general population. Serum anti-HEV positive rate was $13.92 \%$ in Yunnan region, China ${ }^{73}$. HEV infection rate was $16.13 \%$ in male in contrast to females $10.97 \%$, however the highest cases were found among the age group of 20-30 years in both men and women. Farmers exhibited high HEV infection rate (20.35\%) and showed that poor health and living condition and regular contact with animals might have caused above phenomenon. In another study a total of 1500 healthy children were screened for the presence of anti-HEV antibodies and out of these $14.93 \%$ were found positive for HEV seroprevalence ${ }^{74}$. Blood tests of the workers, in seafood processing plants also revealed the presence of anti-HEV IgG antibody and persons handling the crude seafood had higher anti-HEV IgG (32.54\%) than those handling semi-processed items $(24.74 \%)^{75}$. A study conducted in 4 ethnic (Naxi, Bulang, Wa and Hani) population in China detailed the predominance of IgG in Hani, Naxi and Bulang than in Wa ethnic individuals. Univariable analysis showed that HEV IgG pervasiveness was related with origin, gender, education level, smoking habit, body fat ratio and visceral fat index. Study additionally stressed that there might be tendency for eating half-cooked or crude meat and drinking from dairy animals and goat's crude milk as one of the reason of high HEV IgG in these ethnic people. On the other hand, HEV IgG pervasiveness was most elevated in Hani ethnic group (82.3\%) 
as they have the habit of eating raw pork liver and fresh blood from pigs, goats and dogs ${ }^{76}$. An investigation in Dhaka city of Bangladesh had shown $30 \%$ cases of HEV among the healthy urban individuals, and has shown relentless increase among persons over 60 years of age. In 18-40 years of age group the prevalence of anti-HEV IgG is nearly double in females than that in males; however, the study did not define the actual causes of $\mathrm{HEV}$ in report ${ }^{77}$. Study in Laos villages figured out the higher anti-HEV IgG seropositivity rates among the people who were in close contact with cattle and had 3 times higher probability to be seropositive than members without contact. Consumption of crude animal organs, blood, or risky water was not related with high anti-HEV IgG seropositivity and overall $7.0 \%$ of the ruminants had antibodies against HEV, yet this study did not report direct or indirect zoonotic transmission from cattle ${ }^{78}$. In Lop Buri and Narathiwat provinces of Thailand, $37.3 \%$ and $8.9 \%$ of anti-HEV IgG were found in healthy persons. Majority of residents such as abattoir worker, animal transporters, swine farmers, pork handlers or consumers in Lop Buri who follows Buddhism have no restrictions on consuming pork products and these individuals had the chances to get exposed to HEV. These factors may therefore increases the exposure of HEV in Lop Buri populations, whereas, most Narathiwat residents stick to Islam and were not engaged in any swine related activity and showed less HEV among them ${ }^{79}$. During 2015 and 2016, $30.9 \%$ seroprevalence cases of HEV were noticed among the healthy people of Jordan ${ }^{80}$. The study showed that the individuals with formal education had significantly lower HEV seroprevalence as compared to those who had no education.
Interestingly, eating undercooked meat was highly associated with HEV seropositivity. In Denizli province of Turkey, $12.4 \%$ Anti-HEV seroprevalence was found among the healthy primary school kids in $2013^{81}$. Anti-HEV antibodies were found positive in 17 (18.1\%) kids of the age group seven-year, and $6(6.6 \%)$ kids of the age group fourteen-year among 185 grade school youngsters. There was no association between the anti-HEV antibody and gender, parental educational level, and socioeconomic level, and concluded that insufficient sanitation could be the reason for such prevalence. Cases Related to Acute and Chronic Viral Hepatitis Patients

Acute viral hepatitis is exhibited by symptoms, such as darkened urine, uncolored stool, vomiting, myalgia, weakness and jaundice. Serological markers include high levels of liver transaminases, bilirubin, alkaline phosphatases and $\beta$-glutamyltransferase, and detection of anti-HEV IgG/IgM antibodies and HEV-RNA in serum and stool ${ }^{82}$. HEV-4 genotype were found among the acute viral hepatitis (AVH) patients in Shandong province of China and showed that direct contact with pigs, pig farmers; workers in meat handling plant; ingestion of pork, pork items and crude vegetables are essential epidemiological elements that related with HEV infection ${ }^{83}$. An outbreak of HEV in old age nursing home people in Japan showed that some uncooked food items were responsible for such infection ${ }^{84}$. In Mongolia, 20.8\% human HEV cases were reported in AVH patients ranging between the years 2014-2015 and $99.8 \%$ isolates showed their nucleotide sequence closeness with Nepalese genotype 1. It was presumed that in Mongolia, people with HEV infection or contaminated food came from Nepal

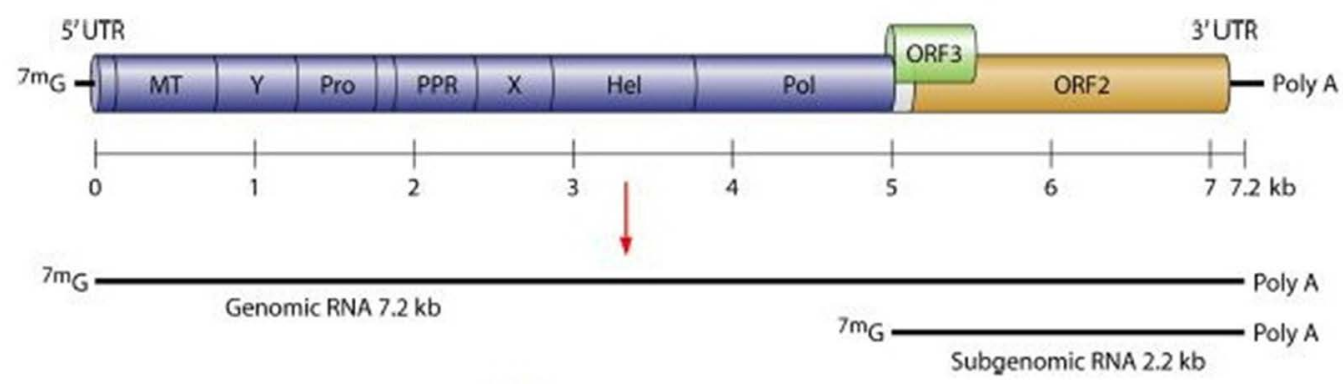

Fig. 1. Hepatitis E virus genome. Where, $M T=$ Methyltransferase; Pro= Cysteine protease; $P P R=P r o l i n e-$ rich hinge domain Hel= RNA helicase; $\mathrm{Pol}=\mathrm{RNA}$ - dependent RNA polymerase; $\mathrm{X}=$ Macrodomain $^{129}$ 
and other neighboring countries and brought genotype $1 \mathrm{HEV}$ strain ${ }^{85}$. An episode of acute hepatitis $E$ in a hospital of Bangladesh showed 13 patients with history of jaundice although their etiological factors were unknown, but most of the patients shared common drinking water, common cooking and dining facilities and even two persons showed acute hepatitis ${ }^{86}$. Epidemic of HEV occurred in one of the province (Biratnagar) in Nepal in 2014 and > 7,000 patients were affected during this epidemic and the epidemic was presumed to be caused by the drinking water. In 2014, water and sewerage pipelines were harmed in various territories of Biratnagar amid development, and, repair of streets and serum tests from $48 \mathrm{AVH}$ patients demonstrated the presence of IgG, IgM and IgA against HEV and all the isolates belonged to genotype $1 a^{87}$. Patient with chronic HEV infection also secreted HEV-RNA and HEV-Ag persistently in urine ${ }^{88}$.

\section{Cases Related to High Risk Patients}

Hepatitis E virus (HEV) infection was earlier thought to be a self-limiting disease having no risk of chronicity. But recently several chronic cases of hepatitis $E$ have been reported among immunosuppressed patients ${ }^{89}$. Over all rate of HEV among the HIV patients in China were $44.68 \%$ and the anti-HEV prevalence expanded by $4.1 \%$ every year with patient's age. Beside age the other factors such as gender, CD4 cell count, WHO stage, marital status and total cholesterol levels are other risk factors that are associated with HEV co-infection in HIV-infected population ${ }^{90}$. Another investigation from China additionally detailed the HEV among disease patients and the rate was $26.0 \%$ and the highest HEV seropervalence occurred in patients with leukemia followed by liver and gastric cancer. This study showed that the HEV seroprevalence was higher in cancer patients than in controls (Healthy people) $(26.03 \%$ versus $13.0 \%)$. The diseased patients are normally immuno-suppressed or immunocompromised, and received blood transfusions, immunosuppressive medications or cancer chemotherapy which prompts their higher vulnerability to HEV. In rural cancer patients the seroprevalence of HEV was $27.8 \%$ marginally higher and pigs act as main reservoir of $\mathrm{HEV}$ in these areas as compared to urban cancer patients $(24.2 \%)^{91}$. Prevalence of HEV was also examined in the Nepalese HIV

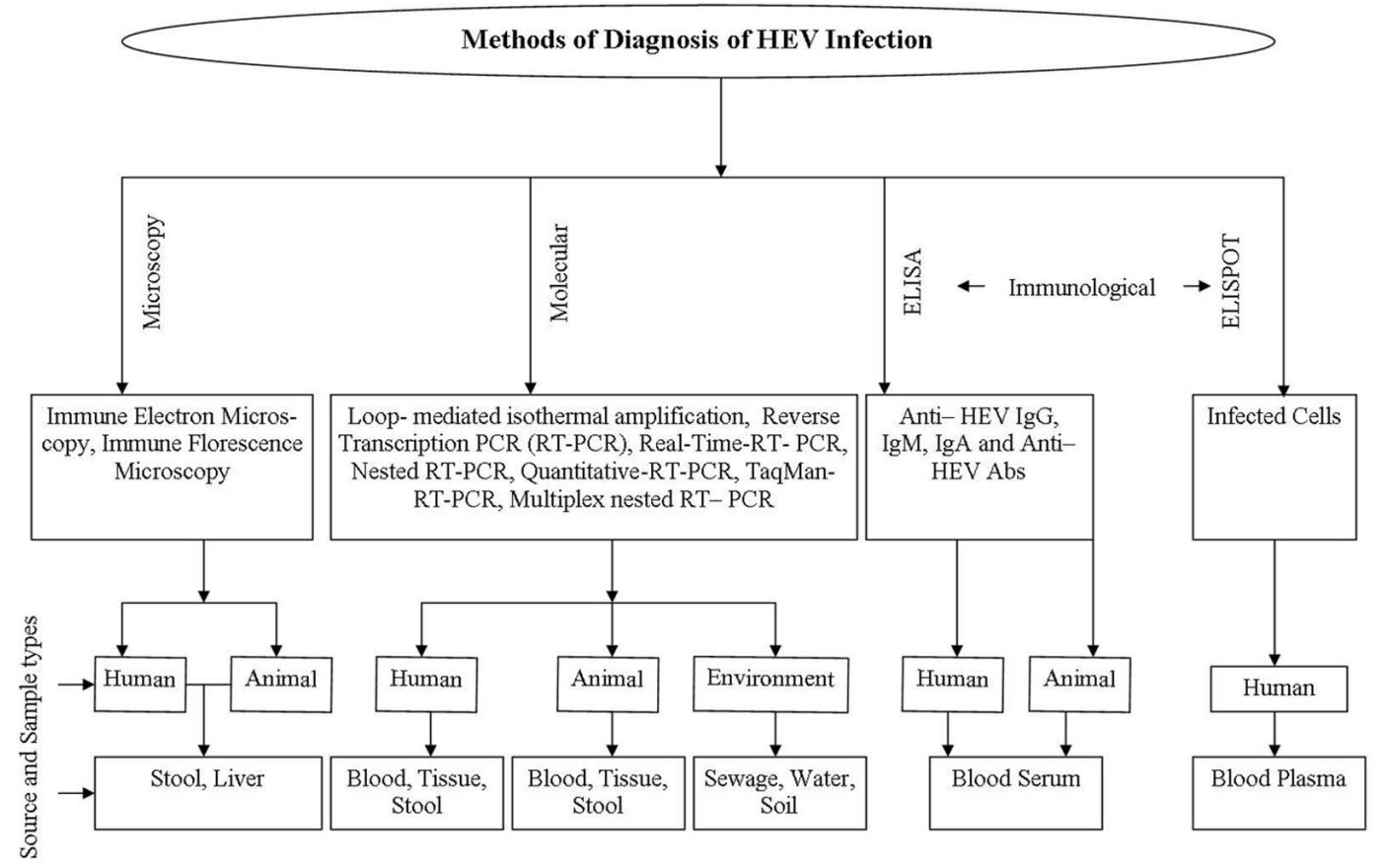

Fig. 2. Different approaches used for the diagnosis of Hepatitis $E$ virus (HEV) ${ }^{6,130-133}$ 
infected patients and in general anti-HEV IgG and anti-HEV IgM similarity was $76.8 \%$ and $28.8 \%$, respectively, in HIV-positive patients living in Kathmandu as well as outside Kathmandu ${ }^{92}$. An examination of kids with neurological issues, immune deficient kids and healthy kid's sera tests in Russia revealed the higher presence of anti-HEV IgG among immune deficient in contrast with healthy kids. Besides this anti-HEV IgM rate was higher (1.1-1.6\% versus $0.25 \%$ ) in immune deficient in contrast with healthy children. This study stressed that immune suppression is a factor of increased risk of infection in children with HEV ${ }^{93}$. Study from Iranian hospital showed the presence of anti-HEV antibody among the patients with end stage renal disease (10.6\%), but failed to report any association between $\mathrm{HEV}$, age, gender, duration of hemodialysis (HD), and HCV antibody among the patients ${ }^{94}$. Another study conducted on high risk patients showed $10.0 \%$ and $1.8 \%$ of antiHEV IgG and IgM antibodies respectively among the thalassemic patients and the seroprevalence of IgG increased with age, raising from $0 \%$ in patients below 10 years to $10 \%$ above 10 years of age group ${ }^{95}$. Study emphasized the importance of HEV infection concerning blood multi-transfusion and possibility that the virus could be parenteral exposed or there is another possibility of shared route of transmission.

\section{Cases Related to Pregnancy}

In developing countries, the incidence of HEV infection in pregnancy is high and a significant proportion of pregnant women shows mortality rate varying from $30-100 \%{ }^{96}$. However the severe liver injury in pregnant women with Hepatitis $E$ remains unknown. In Pakistan, $15.55 \%$ of HEV cases were reported among the pregnant women admitted in various hospitals and none of ladies had jaundice of pregnancy or hepatocellular carcinoma at the time of hospital admission ${ }^{97}$. The study showed that HEV infection increased with repeated exposure of virus, and during pregnancy the severity increases with every trimester and it was more predominant in multigravida ladies and in third trimester, all the babies that were born from infected mothers survived. In Urmia an Iranian city, researchers have reported presence of anti-HEV IgG antibody (3.6\%) among the healthy pregnant ladies and none of the subject had history of blood transfusion and tattooing or
Hijma. The study did not show any significance between age, pregnancy time, gestational age and income level and concluded that low level of HEV among pregnant ladies may be related with better sanitation, efficient health system and arrangement for safe water than other locales of Iran ${ }^{98}$. Another examination on HEV among the pregnant ladies was conducted in Bushehr the biggest province of Iran and the rate was 6.3\% ${ }^{99}$. The Bushehr city is having seaport with a high migration flow, and this may be the solid reason of high seroprevalence of HEV in this city.

\section{Cases Related to Sewage}

HEV, which is shed in the feces of infected individuals and animals, has been detected in sewage samples, suggesting that HEV contamination of aquatic environments may also be present ${ }^{100}$. In China $1.32 \%$ of HEV was found in sewage plants and BLAST analysis showed 95\%99\% nucleotide sequence similarity with swine isolates and belonged to genotype $4^{101}$. A report from Israel found 8.8\% HEV RNA in the sewage water and $6.1 \%$ among the hepatitis patients respectively ${ }^{102}$. All of these patients' and sewage samples sequences belonged to genotype 1 and genotype 3, respectively.

\section{Diagnosis and Vaccine}

Various approaches including demonstrative and diagnostic procedures were applied for confirming and collecting information for HEV. Elevated values of liver parameters at routine intervals, including alanine amino-transferase (ALT), aspartate aminotransferase (AST), bilirubin, gamma-glutamyl transpeptidase, and soluble phosphate are delicate yet nonspecific, marker of liver damage ${ }^{103}$. Immune electron microscopy (IEM) identifies infection like particles in fecal samples and, in this method HEV particles were precipitated with native antibody to recover HEV from sera ${ }^{104}$. HEV antigen can be detected in liver tissue utilizing immune fluorescence microscopy in which liver biopsy tissue having HEV particles are absorbed with fluorescent labeled anti-HEV IgG antibody and complex are watched with microscope equipped with epifluorescent gadget ${ }^{105}$. The various approaches used for identification of HEV are shown in figure 2.

Patients' initial introduction, timely collection of feces or serum samples and suitable transport and processing determined the 
sensitivity of the molecular test employed for the detection of HEV RNA. In this way, untraceable viral RNA does not get ruled out from HEV infection ${ }^{106}$. The HEV RNA can be recognized in the beginning of illness and up to 6 months in stool and serum thus, reduces the catch window for HEV ${ }^{107}$. The detection of viral RNA in biological example is the gold standard for identification of acute HEV hepatitis as nucleic acid amplification techniques (NATs) can precisely recognize active infection and help in affirming serological findings ${ }^{108}$. On the other hand NAT-based identification is a costly methodology that is generally not available at diagnostic research centers, and also it requires exceptionally specialized techniques and trained work force ${ }^{109}$. Over the couple of years, a few NAT tests based on reverse transcription followed by $P C R$, real-time PCR, and reverse transcription loop-mediated isothermal amplification have been reported for identification and detection of HEV RNA in serum and stool samples. For the detection of four human HEV genotypes, NATs assays have been designed and optimized broadly ${ }^{110-112}$.

Extraordinary fluctuation has been seen in the execution of in-house tests because of the non- standardized nature of the HEV nucleic acid detection methods ${ }^{113}$. For the detection of hepatitis A, B, C and E nucleic acids in sera of infected patients, a single step-multiplex RT-PCR was created in which the conserved regions of all the viral genomes were used as target sequence for amplification and the method was found to be rapid, sensitive, precise and reproducible in nature. The detection limit was found to be 280 copies/ml for hepatitis A virus; for hepatitis B 290copies/ml; for hepatitis C 30copies/ml and 300 copies/ml for hepatitis $E$ in a single tube assay system ${ }^{114}$.

A very little knowledge regarding immunological parts of the HEV infection was available until a pattern of antibody response to HEV was recognized and studied. Anti-HEV IgM appears in the acute phase of the HEV infection and is detectable 4 days after the beginning of jaundice and holds on for 5 months ${ }^{115}$. Generally, $90 \%$ of patients suffering with acute hepatitis $E$ infection show presence of detectable anti-HEV IgM within 14 days of infection, while anti-HEV IgG antibodies are noticeable soon after the presence of anti-HEV $\operatorname{IgM}^{115}$. The way these two classes of antibodies develop at the same time in acute infection makes it hard to build up a precise serological conclusion of acute HEV infection. Therefore, conventional immunoassays for IgM are only effective from $90 \%$ to $97 \%$, with false positive aftereffects of up to $2.5 \%$ and a few of these results also create false negative outcomes in patients infected with genotype 1 strains ${ }^{116-118}$. ORF2 and ORF3 antigens and immunodominant peptides are broadly utilized for recognizing IgM, IgG, and IgA antibodies against HEV in commercial HEV serological tests ${ }^{119,120}$. The cross-serological reactivity of HEV with other viruses acknowledged to causes hepatitis was also additionally researched ${ }^{121}$. Most of the research is engaged to the analysis of acute HEV infection in immunosuppressed patients, for example, AIDS, leukemia and lymphoma and also solid organ transplant beneficiaries. During serological testing those conditions of patients must be considered, where seroconversion to anti-HEV antibodies during infection is delayed or may not occur at all. A quantiferon assay has been developed for the fast result of HEV infection ${ }^{122}$. In this assay, a genotype 3a peptide library (616 overlapping peptides spanning open reading frames [ORFs] 13) was used in interferon- gamma (IFN- $\gamma$ ) T- cell ELISpot assay.

Two hepatitis $\mathrm{E}$ immunizations have been assessed in clinical preliminaries and the first of these, rHEV5, was produced by GlaxoSmithKline (GSK, Rixensart, Belgium) ${ }^{123}$. The other HEV 239 (exchange name Hecolin ${ }^{\circledR}$ ), was created by Innovax (Xiamen, China) ${ }^{124-126}$. HEV 239 was authorized in China in 2012 and at present, Hecolin ${ }^{\circledR}$ is accessible in Chinese market and has been affirmed for use in individuals aged more than 16 years. It is used more frequently for inoculating people at high danger of HEV disease, for example, those engaged with creature cultivation, understudies, individuals from the military, sustenance handlers, ladies of childbearing age, and explorers to endemic locales. The Chinese Center for Disease Control and Prevention (CDC) is using an internet framework to gather post-showcasing unfriendly responses/ occasions, and has not recognized any worries with the immunization. In spite of the fact that the current 4.5 years of security and adequacy the information for Hecolin ${ }^{\circledR}$ are reassuring, and the information has not yet been gathered in 
some areas, including pediatric subjects $(<16$ years old), the elderly ( $>65$ years old), pregnant ladies, people with hidden liver sicknesses or the immunosuppressed individuals. These groups confront a more prominent danger of HEV contamination and are consequently in high need of this vaccine ${ }^{123}$.

\section{CONCLUSION}

It is being observed that the incidence of HEV is gradually expanding and its objective range is not only just developing, but also showing enhancement as well. So, in overall, there is need for improvements in detection of HEV disease and methodologies used for the development of HEV vaccines. Advancement of methods using biosensors for the brisk location of HEV in clinical, sustenance and ecological examples is the need of the hour. The research has been done to develop the amperometric sensor for quickly recognizing Streptococcus pyogenes causing rheumatic heart disease; and ultrasensitive transglutaminase based nano-sensor for early detection of celiac disease in human ${ }^{127,128}$. Additionally, consideration is required for more proficiency in planning of HEV vaccines development with new innovations to meet the future requirement.

\section{ACKNOWLEDGEMENTS}

None

\section{CONFLICT OF INTEREST}

The authors declares that there is no conflict of interest.

\section{REFERENCES}

1. WHO. 2018. http://www.who.int/features/qa/76/en/. , Accessed 30 september, 2018.

2. Hall, G.F. Hepatitis A, B, C, D, E, G: an update. Ethnicity \& Disease, 2007; 17: S2-40-S45.

3. Bonino, F., Heermann, K.H., Rizzetto, M., Gerlich, W.H. Hepatitis delta virus: protein composition of delta antigen and its hepatitis $B$ virus-derived envelope. Journal of Virology, 1986; 58(3): 945-950.

4. Khuroo, M.S. Study of an epidemic of non-A, non-B hepatitis: possibility of another human hepatitis virus distinct from post-transfusion non-A, non-B type. American Journal of Medicine, 1980; 68(6): 818-824.

5. Wong, D., Purcell, R., Sreenivasan, M.A., Prasad, S.R., Pavri, K. Epidemic and endemic hepatitis in India: evidence for a non-A, non-B hepatitis virus aetiology. The Lancet, 1980; 316(8200): 876-879.

6. Balayan, M.S., Andjaparidze, A.G., Savinskaya, S.S.,
Ketiladze, E.S., Braginsky, D.M., Savinov, A.P, Poleschuk, V.F. Evidence for a virus in non-A, non-B hepatitis transmitted via the fecal-oral route. Intervirology, 1983; 20(1): 23-31.

7. Reyes, G.R., Purdy, M.A., Kim, J.P., Luk, K.C., Young, L.M., Fry, K.E., Bradley, D.W. Isolation of a cDNA from the virus responsible for enterically transmitted non-A, non-B hepatitis. Science, 1990; 247(4948): 1335-1339.

8. Yamashita, T., Mori, Y., Miyazaki, N., Cheng, R.H., Yoshimura, M., Unno, H., Shima, R., Moriishi, K., Tsukihara, T., Li, T.C., Takeda, N. Biological and immunological chara-cteristics of hepatitis E virus-like particles based on the crystal structure. Proceedings of National Academy of Sciences, 2009; 106(31): 1298612991.

9. Tam, A.W., Smith, M.M., Guerra, M.E., Huang, C.C., Bradley, D.W., Fry, K.E., Reyes, G.R. Hepatitis E virus (HEV): molecular cloning and sequencing of the fulllength viral genome. Virology, 1991; 185(1): 120-131.

10. Koonin, E.V., Gorbalenya, A.E., Purdy, M.A., Rozanov, M.N., Reyes, G.R., Bradley, D.W. Computer-assisted assignment of func-tional domains in the nonstructural polyprotein of hepatitis $E$ virus: deli-neation of an additional group of positive-strand RNA plant and animal viruses. Proceedings of National Academy of Sciences, 1992; 89(17): 8259-8263.

11. Li, T.C., Yamakawa, Y., Suzuki, K., Tatsumi, M., Razak, M.A., Uchida, T., Takeda, N., Miyamura, T. Expression and self-assembly of empty virus-like particles of hepatitis E virus. Journal of Virology, 1997; 71(10): 7207-7213.

12. He, S., Miao, J., Zheng, Z., Wu, T., Xie, M., Tang, M., Zhang, J., Ng, M.H., Xia, N. Putative receptor-binding sites of hepatitis E virus. Journal of General Virology, 2008; 89(1): 245-249.

13. Kalia, M., Chandra, V., Rahman, S.A., Sehgal, D., Jameel, S. Heparan sulfate prote-oglycans are required for cellular binding of the hepatitis E virus ORF2 capsid protein and for viral infection. Journal of Virology, 2009; 83(24): 12714-12724.

14. Xing, L., Wang, J.C., Li, T.C., Yasutomi, Y., Lara, J., Khudyakov, Y., Schofield, D., Emerson, S.U., Purcell, R.H., Takeda, N., Miyamura, T. Spatial configuration of hepatitis E virus antigenic domain. Journal of Virology, 2011; 85(2): 1117-11124.

15. Guu, T.S., Liu, Z., Ye, Q., Mata, D.A., Li, K., Yin, C., Zhang, J., Tao, Y.J. Structure of the hepatitis E virus-like particle suggests mechanisms for virus assembly and receptor binding. Proceedings of National Academy of Sciences, 2009; 106(31): 12992-12997.

16. Tang, X., Yang, C., Gu, Y., Song, C., Zhang, X., Wang, Y., Zhang, J., Hew, C.L., Li, S., Xia, N., Sivaraman, J. Structural basis for the neutralization and genotype specificity of hepatitis E virus. Proceedings of National Academy of Sciences, 2011; 108(25): 10266-10271.

17. Xing, L., Li, T.C., Mayazaki, N., Simon, M.N., Wall, J.S., Moore, M., Wang, C.Y., Takeda, N., Wakita, T., Miyamura, T., Cheng, R.H. Structure of hepatitis E virion-sized particle reveals an RNA-dependent viral assembly pathway. Journal of Biological Chemistry, 2010; 285(43): 33175-33183.

18. Meng, J., Dai, X., Chang, J.C., Lopareva, E., Pillot, 
J., Fields, H.A., Khudyakov, Y.E. Identification and characterization of the neutralization epitope (s) of the hepatitis E virus. Virology, 2001; 288(2): 203-211.

19. Emerson, S.U., Nguyen, H.T., Torian, U., Burke, D., Engle, R., Purcell, R.H. Release of genotype 1 hepatitis E virus from cultured hepatoma and polarized intestinal cells depends on open reading frame 3 protein and requires an intact PXXP motif. Journal of Virology, 2010; 84(18): 9059-9069.

20. Yamada, K., Takahashi, M., Hoshino, Y., Takahashi, H., Ichiyama, K., Nagashima, S., Tanaka, T., Okamoto, H. ORF3 protein of hepatitis $E$ virus is essential for virion release from infected cells. Journal of General Virology, 2009; 90(8): 1880-1891.

21. Graff, J., Torian, U., Nguyen, H., Emerson, S.U. A bicistronic subgenomic mRNA encodes both the ORF2 and ORF3 proteins of hepatitis E virus. Journal of Virology, 2006; 80(12): 5919-5926.

22. Arankalle, V.A., Paranjape, S., Emerson, S.U., Purcell, R.H., Walimbe, A.M. Phylogenetic analysis of hepatitis E virus isolates from India (1976-1993). Journal of General Virology, 1999; 80 (7): 1691-1700.

23. Chandra, V., Taneja, S., Kalia, M., Jameel, S. Molecular biology and pathogenesis of hepatitis E virus. Journal of Biosciences, 2008; 33(4): 451-464.

24. Haqshenas, G.S.H.L., Shivaprasad, H.L., Woolcock, P.R., Read, D.H., Meng, X.J. Genetic identification and characterization of a novel virus related to human hepatitis E virus from chickens with hepatitis-splenomegaly syndrome in the United States. Journal of General Virology, 2001; 82(10): 2449-2462.

25. Huang, F.F., Sun, Z.F., Emerson, S.U., Purcell, R.H., Shivaprasad, H.L., Pierson, F.W., Toth, T.E., Meng, X.J. Determination and analysis of the complete genomic sequence of avian hepatitis E virus (avian HEV) and attempts to infect rhesus monkeys with avian HEV. Journal of General Virology, 2004; 85(6): 1609-1618.

26. Dalton, H.R., Izopet, J. Transmission and epidemiology of hepatitis E virus genotype 3 and 4 infections. Cold Spring Harbor Perspectives in Medicine, 2018; 8(11): a032144.

27. Kamar, N., Izopet, J., Pavio, N., Aggarwal, R., Labrique, A., Wedemeyer, H., Dalton, H.R. Hepatitis E virus infection. Nature Reviews Disease Primers, 2017; 3: 1-16.

28. Katiyar, H., Goel, A., Sonker, A., Yadav, V., Sapun, S., Chaudhary, R., Aggarwal R. Prevalence of hepatitis E virus viremia and antibodies among healthy blood donors in India. Indian Journal of Gastroenterology, 2018; 37(4): 342-346.

29. Arora, D., Jindal, N., Shukla, R.K., Bansal, R. Water borne hepatitis $A$ and hepatitis $E$ in malwa region of punjab, India. Journal of Clinical and Diagnostic Research, 2013; 7(10): 2163-2166.

30. Awsathi, S., Rawat, V., Rawat, C.M.S., Semwal, V., Bartwal, S.J. Epidemiological investigation of the jaundice outbreak in Lalkuan, Nainital district, Uttarakhand. Indian Journal of Community Medicine, 2014; 39(2): 94-97.

31. Singh, M.P., Majumdar, M., Goyal, K., Lakshmi, P.V.M., Bhatia, D., Ratho, R.K. Investigation of suspected viral hepatitis outbreaks in North West India. Diagnostic
Microbiology and Infectious Disease, 2015; 84(4): 3093014.

32. Majumdar, M., Singh, M.P., Goyal, K., Chawla, Y., Ratho, R.K. Detailed investigation of ongoing subclinical hepatitis $E$ virus infections; occurring in outbreak settings of North India. Liver International, 2015; 35(3): 826-833.

33. Kaur, M., Sidhu, S.K., Singh, K., Devi, P., Kaur, M., Singh, N.J. Hepatitis $E$ virus: A leading cause of waterborne viral hepatitis in Northwest Districts of Punjab, India. Journal of Laboratory Physicians, 2017; 9(2): 121-124.

34. Khuroo, M.S., Kamili, S., Khuroo, M.S. Clinical course and duration of viremia in vertically transmitted hepatitis $E$ virus (HEV) infection in babies born to HEV-infected mothers. Journal of Viral Hepatitis, 2009; 16(7):519-523.

35. Singh, N.J., Kumar, A., Catanzaro, R., Marotta, F. Prevalence of hepatitis $E$ and hepatitis $B$ dual infection in North India (Delhi). Acta Bio Medica Atenei Parmensis, 2012; 83(3): 197-201.

36. Gajjar, M.D., Bhatnagar, N.M., Sonani, R.V., Gupta, S., Patel, T. Hepatitis E seroprevalence among blood donors: A pilot study from Western India. Asian Journal of Transfusion Science, 2014; 8(1): 29-31.

37. Chandra, N.S., Ojha, D., Chatterjee, S., Chattopadhay, D. Prevalence of hepatitis $E$ virus infection in West Bengal, India: a hospital-based study. Journal of Medical Microbiology, 2014; 63(7): 975-980.

38. Jain, P., Parkash, S., Gupta, S., Singh, K.P., Shrivastava, S., Singh, D.D., Singh, J., Jain, A. Prevalence of hepatitis A virus, hepatitis $B$ virus, hepatitis $C$ virus, hepatitis $D$ virus and hepatitis $E$ virus as cause of acute viral hepatitis in North India: A hospital based study. Indian Journal of Medical Microbiology, 2013; 31(3): 261-265.

39. Gupta, E., Pandey, P., Pandey, S., Sharma, M.K. Role of hepatitis $E$ virus antigen in confirming active viral replication in patients with acute viral hepatitis $E$ infection. Journal of Clinical Virology, 2013; 58(2): 374-377.

40. Vivek, R., Zachariah, U.G., Ramachandran, J., Eapen, C.E., Rajan, D.P., Kang, G. Characterization of hepatitis $E$ virus from sporadic hepatitis cases and sewage samples from Vellore, south India. Transactions of the Royal Society of Tropical Medicine and Hygiene, 2013; 107(6): 363-367.

41. Bansal, M., Kaur, S., Deka, D., Singh, R., Gill, J.P.S. Seroepidemiology and molecular characterization of hepatitis E virus infection in swine and occupationally exposed workers in Punjab, India. Zoonoses and Public Health, 2017; 64(8): 662-672.

42. Naik, A., Gupta, N., Goel, D., Ippagunta , S.K., Sharma, R.K., Aggarwal, R. Lack of evidence of hepatitis E virus infection among renal transplant recipients in diseaseendemic area. Journal of Viral Hepatitis, 2013; 20: e138-e140.

43. IDSP India. Weekly Outbreaks. 2018. http://www.idsp. nic.in., Accessed 1 october, 2018.

44. Wang, B., Cai, C.L., Li, B., Zhang, W., Zhu, Y., Chen, W.H., Zhuo, F., Shi, Z.L., Yang, X.L. Detection and characterization of three zoonotic viruses in wild rodents and shrews from Shenzhen city, China. Virologica Sinica, 2017; 32(4): 290-297. 
45. Li, W., Guan, D., Su, J., Takeda, N., Wakita, T., Li, T.C., $\mathrm{Ke}, \mathrm{C} . \mathrm{W}$. High prevalence of rat hepatitis $\mathrm{E}$ virus in wild rats in China. Veterinary Microbiology, 2013; 165(3-4): 275-280.

46. Xia, J., Zeng, H., Liu, L., Zhang, Y., Liu, P., Geng, J., Wang, L., Wang, L., Zhuang, H. Swine and rabbits are the main reservoirs of hepatitis E virus in China: detection of HEV RNA in feces of farmed and wild animals. Archives of Virology, 2015; 160(11): 2791-2798.

47. Yang, S., Wang, L., Sun, S. Natural infection with avian hepatitis $\mathrm{E}$ virus and Marek's disease virus in brown layer chickens in China. Avian Disease, 2016; 60(3): 698-704.

48. Zhang, L., Li, K., Huang, S., Liu, D., Rehman, M.U., Lan, Y., Zhang, H., Wang, L., Hao, Y., lqbal, M.K., Mehmood, K. Seroprevalence and risk factors associated with hepatitis $\mathrm{E}$ virus infections among people and pigs in Tibet, China. Acta Tropica, 2017; 172: 102-106.

49. Zhang, L., Huang, S., Li, K., Rehman, M.U., Jiang, X., Tong, X., Zhang, H., Iqbal, M.K., Mehmood, K., Liu, S., Shen, Y. Molecular detection of indigenous hepatitis $E$ virus (HEV) from Tibetan pigs in Tibet, China. Food and Environmental Virology, 2018; 10(4): 373-377.

50. Long, F., Yu, W., Yang, C., Wang, J., Li, Y., Li, Y., Huang F. High prevalence of hepatitis $E$ virus infection in goats. Journal of Medical Virology, 2017; 89: 1981-1987.

51. Li, S., Liu, M., Cong, J., Zhou, Y., Miao, Z. Detection and characterization of hepatitis $E$ virus in goats at slaughter-house in Tai'an Region, China. BioMed Research International, 2017; 1-5.

52. Wu, J., Si, F., Jiang, C., Li, T., Jin, M. Molecular detection of hepatitis $E$ virus in sheep from southern Xinjiang, China. Virus Genes, 2015; 50(3): 410-417.

53. Chan, M.C., Kwok, K., Hung, T.N., Chan, P.K. Molecular epidemiology and strain comparison between hepatitis E virus in human sera and pig livers during 2014-2016 in Hong Kong. Journal of Clinical Microbiology, 2017; 55: 1408-1415.

54. Motoya, T., Nagata, N., Komori, H., Doi, I., Kurosawa, M., Keta, T., Sasaki, N., Ishii, K. The high prevalence of hepatitis $E$ virus infection in wild boars in Ibaraki Prefecture, Japan. Journal of Veterinary Medical Science, 2015; 77(12): 1705-1709.

55. Sasaki, Y., Haruna, M., Uema, M., Noda, M., Yamada, Y. Prevalence and phylogenetic analysis of hepatitis E virus among pigs in Japan. Japanese Journal of Infectious Diseases, 2018; 71(1): 75-78.

56. Kobayashi, T., Murakami, S., Yamamoto, T., Mineshita, K., Sakuyama, M., Sasaki, R., Maeda, K., Horimoto, T. Detection of bat hepatitis $E$ virus RNA in microbats in Japan. Virus Genes, 2018; 54: 599-602.

57. Kim, Y.H., Park, B.J., Ahn, H.S., Han, S.H., Go, H.J., Kim, D.H., Lee, J.B., Park, S.Y., Song, C.S., Lee, S.W., Choi, I.S. Detection of hepatitis E virus genotypes 3 and 4 in pig farms in Korea. Journal of Veterinary Science, 2018; 19(2): 309-312.

58. Ahn, H.S., Park, B.J., Han, S.H., Kim, Y.H., Kim, D.H., Kim, B.S., Lee, J.B., Park, S.Y., Song, C.S., Lee, S.W., Choi, I.S. Prevalence and genetic features of rabbit hepatitis E virus in Korea. Journal of Medical Virology, 2017; 89(11): 1995-2002.

59. Han, S.H., Park, B.J., Ahn, H.S., Kim, Y.H., Go, H.J., Kim,
D.H., Lee, J.B., Park, S.Y., Song, C.S., Lee, S.W., Choi, I.S. Evidence of hepatitis $E$ virus infection in specific pathogen-free rabbits in Korea. Virus Genes, 2018; 54 : 587-590.

60. Hsu, I.W.Y., Tsai, H.J. Avian hepatitis E virus in chickens, Taiwan, 2013. Emerging Infectious Diseases, 2014; 20(1): 149-151.

61. Khounvisith, V., Tritz, S., Khenkha, L., Phoutana, V., Keosengthong, A., Pomma-sichan S., Nouanthong, P., H bschen, J.M., Snoeck, C.J., Reinharz, D., Muller, C.P. High circulation of Hepatitis $\mathrm{E}$ virus in pigs and professionals exposed to pigs in Laos. Zoonoses and Public Health, 2018; 65(8): 1020-1026.

62. Intharasongkroh, D., Sa-nguanmoo, P., Tuanthap, S., Thongmee, T., Duang-in, A., Klinfueng, S., Chansaenroj, J., Vongpunsawad, S., Theamboonlers, A., Payungporn, S., Chirathaworn, C. Hepatitis Evirus in pork and variety meats sold in fresh markets. Food and Environmental Virology, 2017; 9(1): 45-53.

63. Woo, P.C., Lau, S.K., Teng, J.L., Tsang, A.K., Joseph, M., Wong, E.Y., Tang, Y., Sivakumar, S., Xie, J., Bai, R., Wernery, R. New hepatitis $E$ virus genotype in camels, the Middle East. Emerging Infectious Diseases, 2014; 20(6): 1044-1048.

64. Kumar, N., Sarin, S.K. Heaptitis E-Is it a risk to transfusion safety? Asian Journal of Transfusion Science, 2013; 7(1): 1-3.

65. Gupta, B.P., Lama, T.K., Adhikari, A., Shrestha, A., Rauniyar, R., Sapkota, B., Thapa, S., Shrestha, S., Gupta, P.P., Manandhar, K.D. First report of hepatitis $E$ virus viremia in healthy blood donors from Nepal. VirusDisease, 2016; 27(3): 324-326.

66. Shrestha, A.C., Flower, R.L., Seed, C.R., Rajkarnikar, M., Shrestha, S.K., Thapa, U., Hoad, V.C, Faddy, H.M. Hepatitis $\mathrm{E}$ virus sero-epidemiology: a post-earthquake study among blood donors in Nepal. BMC Infectious Diseases, 2016; 16(1): 707.

67. Nouhin, J., Prak, S., Madec, Y., Barennes, H., Weissel, R., Hok, K., Pavio, N., Rouet, F. Hepatitis E virus antibody prevalence, RNA frequency, and genotype among blood donors in Cambodia (Southeast Asia). Transfusion, 2016; 56(10): 2597-2601.

68. Farshadpour, F., Taherkhani, R., Makvandi, M. Prevalence of hepatitis $E$ virus among adults in southwest of Iran. Hepatitis Research and Treatment, 2015; 1-5.

69. Naeimi, B., Kalimani, F.M., Pourfatolah, A.A., Azimzadeh, M., Mankhian, A., Akbarzadeh, S., Hajiani, G., Kooshesh, F., Khamisipour, G. Hepatitis E Virus Seroprevalence among blood donors in Bushehr, South of Iran. Hepatitis Monthly, 2015; 15(11): e29219.

70. Hesamizadeh, K., Sharafi, H., Keyvani, H., Alavian, S.M., Shabankareh, A.N.T., Olyaie, R.S., Keshvari, M. Hepatitis $A$ virus and hepatitis $E$ virus seroprevalence among blood donors in Tehran, Iran. Hepatitis Monthly, 2016; 16(1): e32215.

71. Parsa, R., Adibzadeh, S., Behbahani, A.B., Farhadi, A., Yaghobi, R., Dehbidi, G.R.R., Hajizamani, S., Rahbar, S., Nikouyan, N., Okhovat, M.A., Naderi, S. Detection of hepatitis $E$ virus genotype 1 among blood donors from Southwest of Iran. Hepatitis Monthly, 2016; 16(6): e34202. 
72. Nasrallah, G.K., Al-Absi, E.S., Ghandour, R., Ali, N.H., Taleb, S., Hedaya, L., Ali, F., Huwaidy, M., Husseini, A. Seroprevalence of hepatitis $E$ virus among blood donors in Qatar (2013-2016). Transfusion, 2017; 57(7): 1801-1807.

73. Li, L.J., Shen, Y.Y., Ai, Z.Q., Guo, L., Geng, C.R. Seroepidemiology and genetic chara-cterization of hepatitis E virus in western Yunnan Province. Asian Pacific Journal of Tropical Medicine, 2014; 7(11): 909912.

74. Meng, Q.F., You, H.L., Wang, W.L., Zhou, N., Dong, W., Cong, W. Seroprevalence and risk factors of hepatitis E virus infection among children in China. Journal of Medical Virology, 2015; 87(9): 1573-1577.

75. Cui, W., Sun, Y., Xu, A., Gao, R., Gong, L., Zhang, L., Jiang, $M$. Hepatitis $E$ seroprevalence and related risk factors among seafood processing workers: A cross-sectional survey in Shandong Province, China. International Journal of Infectious Disease, 2016; 49: 62-66.

76. Feng, Y., Feng, Y.M., Wang, S., Xu, F., Zhang, X., Zhang, C., Jia, Y., Yang, W., Xia, X., Yin, J. High seroprevalence of hepatitis $E$ virus in the ethnic minority populations in Yunnan, China. PloS One, 2018; 13(5): e0197577.

77. Rahman, S., Mamun-Al-Mahtab, M.J., Tabassum, S., Akbar, S.M.F. Epidemiology of Hepatitis $E$ Virus in an urban community in dhaka city. Euroasian Journal of Hepatogastroenterology, 2014; 4(1): 4-6.

78. Tritz, S.E., Khounvisith, V., Pommasichan, S., Ninnasopha, K., Keosengthong, A., Phoutana, V., Camoin, M., H bschen, J.M., Black, A.P., Muller, C.P., Snoeck, C.J. Evidence of increased Hepatitis E virus exposure in Lao villagers with contact to ruminants. Zoonoses and Public Health, 2018; 65(6): 690-701.

79. Sa-nguanmoo, P., Posuwan, N., Vichaiwattana, P., Wutthiratkowit, N., Owatanapanich, S., Wasitthankasem, R., Thongmee, T., Poovorawan, K., Theam-boonlers, A., Vongpunsawad, S., Poovorawan, $Y$. Swine is a possible source of hepatitis $E$ virus infection by comparative study of hepatitis $A$ and $E$ seroprevalence in Thailand. PloS One, 2015; 10(4): e0126184.

80. Obaidat, M.M., Roess, A.A. Seroprevalence and risk factors of Hepatitis E infection in Jordan's population: First report. International Journal of Infectious Diseases, 2018; 66: 121-125.

81. Cevahir, N., Demir, M., Bozkurt, A.I., Ergin, A., Kaleli, I. Seroprevalence of hepatitis $E$ virus among primary school children. Pakistan Journal of Medical Sciences, 2013; 29(2): 629-632.

82. Parvez, M.k. Chronic hepatitis E infection: risks and controls. Intervirology, 2013; 56(4): 213-216.

83. Wang, L., Liu, L., Wei, Y., Wang, Q., Tian, Q., Wang, L., Zhuang, H. Clinical and virological profiling of sporadic hepatitis Evirus infection in China. Journal of Infection, 2016; 73(3): 271-279.

84. Ishida, S., Matsuura, K., Yoshizumi, S., Miyoshi, M., Sugisawa, T., Tanida, M., Okano, M. Hepatitis E outbreak at a nursing home for aged people in Hokkaido, Japan, between February and March 2016. Journal of Clinical Virology, 2018; 101: 23-28.

85. Tsatsralt-Od, B., Primadharsini, P.P., Nishizawa, T., Ohnishi, H., Nagashima, S., Takahashi, M., Jirintai, S.,
Nyamkhuu, D., Okamoto, H. Distinct changing profiles of hepatitis $A$ and $E$ virus infection among patients with acute hepatitis in Mongolia: The first report of the full genome sequence of a novel genotype 1 hepatitis $\mathrm{E}$ virus strain. Journal of Medical Virology, 2018; 90(1): 84-92.

86. Al-Mahtab, M., Akbar, S.M.F., Podder, D.C., Saha, P.K., Jahan, M., Begum, L., Afrose, T. An outbreak of acute hepatitis in a medical facility of Bangladesh. Euroasian Journal of Hepatogastroenterology, 2014; 4(1): 66-67.

87. Shrestha, A., Lama, T.K., Karki, S., Sigdel, D.R., Rai, U., Rauniyar, S.K., Al-Mahtab, M., Takahashi, K., Arai, M., Akbar, S.M., Mishiro, S. Hepatitis E epidemic, Biratnagar, Nepal, 2014. Emerging Infectious Diseases, 2015; 21(4): 711-713.

88. Geng, Y., Zhao, C., Huang, W., Harrison, T.J., Zhang, H., Geng, K., Wang, Y. Detection and assessment of infectivity of hepatitis $E$ virus in urine. Journal of Hepatology, 2016; 64(1): 37-43.

89. Renou, C., Lafeuillade, A., Cadranel, J.F., Pavio, N., Pariente, A., Allegre, T., T., Poggi, C., Pיnaranda, G., Cordier, F., Nicand, E. Hepatitis E virus in HIV-infected patients. AIDS, 2010; 24: 1493-1499.

90. Zhou, S., Ren, L., Xia, X., Miao, Z., Huang, F., Li, Y., Zhu, M., Xie, Z., Xu, Y., Qian, Y., Pan, Q. Hepatitis E virus infection in HIV-infected patients: A large cohort study in Yunnan province, China. Journal of Medical Virology, 2018; 90(6): 1121-1127.

91. Bai, M.J., Zhou, N., Dong, W., Li, G.X., Cong, W., Zhu, $X . Q$. Seroprevalence and risk factors of hepatitis $E$ virus infection in cancer patients in eastern China. International Journal of Infectious Diseases, 2018; 71 : 42-47.

92. Shrestha, A., Adhikari, A., Bhattarai, M., Rauniyar, R., Debes, J.D., Boonstra, A., Lama, T.K., Al Mahtab, M., Butt, A.S., Akbar, S.M.F., Aryal, N. Prevalence and risk of hepatitis $E$ virus infection in the HIV population of Nepal. Virology Journal, 2017; 14(1): 228.

93. Potemkin, I.A., Lopatukhina, M.A., Gadzhieva, O.A., Prokhorova, E.L., Diyarrassuba, A., Isaeva, O.A., Kozhanova, T.V., Ivanova, O.E., Silenova, O.V., Setdikova, N., Kyuregyan, K.K. Prevalence of hepatitis E markers in children. Zhurnal Mikrobiologii, Epidemiologii, Immunobiologii, 2015; (2)38-46.

94. Mousavi, S.S.B., Motemednia, F., Mousavi, M.B. Epidemiology of hepatitis $E$ virus infection in patients on chronic hemo-dialysis. Jundishapur Journal of Microbiology, 2014; 7(5): e6993.

95. Jahromi, A.S., Ahmadi-vasmehjani, A., Zabetian, H., Hakimelahi, H., Yusefi, A., Sanie, M.S., Jahromi, S.T., Ghanei, M., Sapidkar, A., Erfanian, S., Madani, A. Sero-epidemiological study of Hepatitis E Virus among Thalassemia as high risk patients: a cross-sectional survey in Jahrom, Southern, Iran. Global Journal of Health Science, 2016; 8(9): 245-250.

96. Navaneethan, U., Al-Mohajer, M., Shata, M.T. Hepatitis $E$ and pregnancy: under-standing the pathogenesis. Liver International, 2008; 28(9): 1190-1199.

97. Javed, N., Ullah, S.H., Hussain, N., Sheikh, M.A., Khan, A., Ghafoor, F., Firdous, R., Uddin, W., Saqib, A.N., Muhyudin, G. Hepatitis E virus seroprevalence in pregnant women in Pakistan: maternal and fetal 
outcomes. East Mediterranean Health Journal, 2017; 23(8): 559-563.

98. Khameneh, Z.R., Sepehrvand, N., Khalkhali, H.R. Seroprevalence of hepatitis $E$ among pregnant women in Urmia, Iran. Hepatitis Monthly, 2013; 13(11): e10931.

99. Farshadpour, F., Taherkhani, R., Ravanbod, M.R., Eghbali, S.S., Taherkhani, S., Mahdavi, E. Prevalence, risk factors and molecular evaluation of hepatitis $E$ virus infection among pregnant women resident in the northern shores of Persian Gulf, Iran. PloS One, 2018; 13(1): e0191090.

100. La Rosa, G., Pourshaban, M., Laconelli, M., Vennarucci, V.S., Muscillo, M. Molecular detection of Hepatitis E virus in sewage samples. Applied Environmental Microbiology, 2010; 76(17): 5870-5873.

101. Li, H., Li, W., She, R., Yu, L., Wu, Q., Yang, J., Hu, F., Soomro, M.H., Shi, R., Hao, W., Zhao, Y. Hepatitis E virus genotype 4 sequences detected in sewage from treatment plants of China. Food and Environmental Virology, 2017; 9(2): 230-233.

102. Ram, D., Manor, Y., Gozlan, Y., Schwartz, E., Ben-Ari, Z., Mendelson, E., Mor, O. Hepatitis E virus genotype 3 in sewage and genotype 1 in acute hepatitis cases, Israel. American Journal of Tropical Medicine and Hygiene, 2016; 95(1): 216-220.

103. Aggarwal, R., Jameel, S. Hepatitis E. Hepatology, 2011; 54(6): 2218-2226.

104. Dienstag, J.L., Alling, D.W., Purcell, R.H. Quantitation of antibody to hepatitis $A$ antigen by Immune Electron Microscopy. Infection and Immunity, 1976; 13(4): 1209-1213.

105. Krawczynski, K., Bradley, D.W. Enterically transmitted non- $A$, non- $B$ hepatitis: identification of virusassociated antigen in experimentally infected cynomolgus macaques. Journal of Infectious Diseases, 1989; 159(6): 1042-1049.

106. Colson, P., Coze, C., Gallian, P., Henry, M., De Micco, P., Tamalet, C. Transfusion-associated hepatitis E, France. Emerging Infectious Diseases, 2007; 13(4): 648-649.

107. Sarin, S.K., Kumar, M. Hepatitis E. In: Boyer, T., Manns, M., Wright, T.L. Hepatology: A Textbook of Liver Disease, pp. 693-724. 5th Ed. Philadelphia, PA: Saunders, 2006

108. Huang, S., Zhang, X., Jiang, H., Yan, Q., Ai, X., Wang, Y., Cai, J., Jiang, L., Wu, T., Wang, Z., Guan, L. Profile of acute infectious markers in sporadic hepatitis E. PloS One, 2010; 5(10): e13560.

109. Mirazo, S., Ramos, N., Mainardi, V., Gerona, S., Arbiza, J. Transmission, diagnosis, and management of hepatitis E: an update. Hepatic Medicine Evidence and Research, 2014; 6: 45-59.

110. Lan, X., Yang, B., Li., B.Y., Yin, X.P., Li, X.R., Liu, J.X. Reverse transcription-loop-mediated isothermal amplification assay for rapid detection of hepatitis $E$ virus. Journal of Clinical Microbiology, 2009; 47(7): 2304-2306.

111. Jothikumar, N., Cromeans, T.L., Robertson, B.H., Meng, X.J., Hill, V.R. A broadly reactive one-step real-time RTPCR assay for rapid and sensitive detection of hepatitis E virus. Journal of Virological Methods, 2006; 131(1): 65-71.
112.

Gyarmati, P., Mohammed, N., Norder, H., Blomberg, J., Belak, S., Wid'n, F. Universal detection of hepatitis $E$ virus by two real-time PCR assays: TaqMan and PrimerProbe Energy Transfer. Journal of Virological Methods, 2007; 146(1-2): 226-235.

113. Baylis, S.A., Hanschmann, K.M., Bl mel, J., N bling, C.M. Standardization of hepatitis E virus (HEV) nucleic acid amplification technique (NAT)-based assays: an initial study to evaluate a panel of HEV strains and investigate laboratory. Journal of Clinical Microbiology, 2011; 49(4): 1234-1239.

114. Irshad, M., Ansari, M.A., Irshad, K., Lingaiah, R. Novel singlestep multiplex real-time polymerase chain reaction assay for simultaneous quantification of hepatitis virus A, B, C, and E in serum. Journal of Gastroenterology and Hepatology, 2013; 28(12): 18691876.

115. Favorov, M.O., Fields, H.A., Purdy, M.A., Yashina, T.L., Aleksandrov, A.G., Alter, M.J., Yarasheva, D.M., Bradley, D.W., Margolis, H.S. Serologic identification of hepatitis $E$ virus infections in epidemic and endemic settings. Journal of Medical Virology, 1992; 36(4): 246-250.

116. Legrand-Abravanel, F., Thevenet, I., Mansuy, J.M., Saune, K., Vischi, F., Peron, J.M., Kamar, N., Rostaing, L., Izopet, J. Good performance of immunoglobulin $M$ assays in diagnosing genotype 3 hepatitis $E$ virus infections. Clinical and Vaccine Immunology, 2009; 16(5): 772-774.

117. Drobeniuc, J., Meng, J., Reuter, G., Greene-Montfort, T., Khudyakova, N., Dimitrova, Z., Kamili, S., Teo, C.G. Serologic assays specific to immunoglobulin $M$ antibodies against hepatitis $E$ virus: pangenotypic evaluation of performances. Clinical Infectious Diseases, 2010; 51(3): e24-27.

118. Herremans, M., Bakker, J., Duizer, E., Vennema, H., Koopmans, M.P. Use of serological assays for diagnosis of hepatitis $E$ virus genotype 1 and 3 infections in a setting of low endemicity. Clinical and Vaccine Immunology, 2007; 14(5): 562-568.

119. Takahashi, M., Kusakai, S., Mizuo, H., Suzuki, K., Fujimura, K., Masuko, K., Sugai, Y., Aikawa, T., Nishizawa, T., Okamoto, H. Simultaneous detection of immuno-globulin A (IgA) and IgM antibodies against hepatitis Evirus (HEV) is highly specific for diagnosis of acute HEV infection. Journal of Clinical Microbiology, 2005; 43(1): 49-56.

120. Zhang, S., Tian, D., Zhang, Z., Xiong, J., Yuan, Q., Ge, S., Jhang, J., Xia, N. Clinical significance of anti-HEV IgA in diagnosis of acute genotype 4 hepatitis $E$ virus infection negative for anti-HEV IgM. Digestive Diseases and Sciences, 2009; 54(11): 2512-2518.

121. Hyams, C., Mabayoje, D.A., Copping, R., Maranao, D., Patel, M., Labbett, W., Haque, T., Webster, D.P. Serological cross reactivity to CMV and EBV causes problems in the diagnosis of acute hepatitis $E$ virus infection. Journal of Medical Virology, 2014; 86(3): 478-483.

122. Brown, A., Halliday, J.S., Swadling, L., Madden, R.G., Bendall, R., Hunter, J.G., Maggs, J., Simmonds, P., Smith, D.B., Vine, L., McLaughlin, C. Characterization of the specificity, functionality, and durability of host $T$-cell responses against the full-length hepatitis $E$ virus. 
Hepatology, 2016; 64(6): 1934-1950.

123. Li, S.W., Zhao, Q., Wu, T., Chen, S., Zhang, J., Xia, N.S. The development of a recombinant hepatitis $E$ vaccine HEV 239. Human Vaccines and Immunotherapeutics, 2015; 11(4): 908-914.

124. Zhang, J., Liu, C.B., Li, R.C., Li, Y.M., Zheng, Y.J., Li, Y.P., Luo, D., Pan, B.B., Nong, Y., Ge, S.X., Xiong, J.H. Randomized-controlled phase II clinical trial of a bacterially expressed recombinant hepatitis $E$ vaccine. Vaccine, 2009; 27(12): 1869-1874.

125. Zhu, F.C., Zhang, J., Zhang, X.F., Zhou, C., Wang, Z.Z., Huang, S.J., Wang, H., Yang, C.L., Jiang, H.M., Cai, J.P., Wang, Y.J. Efficacy and safety of a recombinant hepatitis $E$ vaccine in healthy adults: a large-scale, randomised, double-blind placebo-controlled, phase 3 trial. The Lancet, 2010; 376(9744): 895-902.

126. Wu, T., Li, S.W., Zhang, J., Ng, M.H., Xia, N.S., Zhao, Q. Hepatitis $\mathrm{E}$ vaccine development: a 14 year odyssey. Human Vaccines and Immunotherapeutics, 2012; 8(6): 823-827.

127. Kaushal, A., Singh, S., Kumar, A., Kumar, D. Nano-Au/ cMWCNT modified speB gene specific amperometric sensor for rapidly detecting Streptococcus pyogenes causing rheumatic heart disease. Indian Journal of Microbiology, 2017; 57(1): 112-124.

128. Gupta, S., Kaushal, A., Kumar, A., Kumar, D. Ultrasensitive transglutaminase based nanosensor for early detection of celiac disease in human. International Journal of Biological Macromolecules, 2017; 5: 905-911.

129. Kamar, N., Dalton, H.R., Abravanel, F., Izopet, J. Hepatitis E virus infection. Clinical Microbiology Reviews, 2014; 27(1): 116-138.

130. Parashar, D., Khalkar, P., Arankalle, V.A. Survival of hepatitis $A$ and $E$ viruses in soil samples. Clinical Microbiology and Infection, 2011; 17(11): E1-E4.

131. Aggarwal, R. Hepatitis E: clinical presentation in disease-endemic areas and diagnosis. Seminars in Liver Disease, 2013; 33(1): 30-40.

132. Fujiwara, S., Yokokawa, Y., Morino, K., Hayasaka, K., Kawabata, M., Shimizu, T. Chronic hepatitis E: a review of the literature. Journal of Viral Hepatitis, 2014; 21(2): 78-89.

133. Khuroo, M.S., Khuroo, M.S., Khuroo, N.S. Hepatitis E: discovery, global impact, control and cure. World Journal of Gastroenterology, 2016; 22(31): 7030-7045. 